\title{
52. TECTONIC EVOLUTION OF THE LABRADOR SEA AND BAFFIN BAY: CONSTRAINTS IMPOSED BY REGIONAL GEOPHYSICS AND DRILLING RESULTS FROM LEG 1051
}

\author{
S. P. Srivastava ${ }^{2}$ and M. A. Arthur ${ }^{3}$
}

\begin{abstract}
Results of drilling in the Labrador Sea and Baffin Bay during Leg 105 confirm an earlier interpretation, based on geophysical data, that the crust under the Labrador Sea is oceanic in nature. The oceanic crust at Site 647 in the Labrador Sea (Chron C24; $56 \mathrm{Ma}$ ) confirms the age originally assigned to basement at this site on the basis of the magnetic anomaly identification. The crustal age validates the seafloor-spreading model proposed for the Labrador Sea and Baffin Bay. Rates of crustal subsidence obtained at the Baffin Bay site since Oligocene resemble those obtained from a cooling lithospheric plate. The extrapolation of this rate of subsidence shows that Greenland would have separated from Baffin Island about $63 \mathrm{Ma}$ ago. The presence of depth anomalies, high heat-flow values at the Labrador Sea sites, and the differences and similarities in the chemical composition of the Labrador Sea and Davis Strait basalts all suggest the possibility of a hot spot under the Davis Strait region during the Paleocene.
\end{abstract}

\section{INTRODUCTION}

One of the objectives of drilling in the Labrador Sea and Baffin Bay during Leg 105 was to obtain evidence for the tectonic evolution of these two basins. The basins are confined between the coasts of Labrador and Baffin Island on the west, and Greenland on the east (Fig. 1). They are separated by a shallow bathymetric sill at Davis Strait, which is no deeper than $700 \mathrm{~m}$. These basins differ morphologically from other basins floored by oceanic crust because the typical mid-ocean ridges seen in other basins are not manifested in the Labrador Sea and Baffin Bay regions. These ridges are buried under thick sediments, and their presence is discerned solely from seismic-reflection data. The lack of expression of mid-ocean ridges led some geologists to suggest that these basins were formed by the foundering of continental crust (e.g., Kerr, 1967). Synthesis of a large amount of geological and geophysical data collected in these basins over the past two decades favors the argument that these basins were formed by seafloor spreading (e.g., Srivastava et al., 1981). However, this idea is by no means universally accepted, and the drilling was designed to shed some light on their tectonic evolution.

Because the basement over most of Baffin Bay and the Labrador Sea is deeply buried, in many places it is not possible to drill into the basement rocks with today's technology and time limitations. Potential sites were restricted to drilling to basement rocks on older oceanic crust, which lies at depths greater than $3 \mathrm{~km}$ in most places and has a relatively thin veneer of sediment. Two sites in the Labrador Sea (Site 646 at $58^{\circ} 12.56^{\prime} \mathrm{N}$, $48^{\circ} 22.15^{\prime} \mathrm{W}$ and Site 647 at $53^{\circ} 19.88^{\prime} \mathrm{N}, 45^{\circ} 15.72^{\prime} \mathrm{W}$, Fig. 1 ) and one in Baffin Bay (Site 645 at $70^{\circ} 27.48^{\prime} \mathrm{N}, 64^{\circ} 39.30^{\prime} \mathrm{W}$, Fig.1) were drilled during Leg 105.

The Labrador Sea sites (Fig. 2) were located near marine magnetic anomaly 24 , where drilling to basement at one of the sites (647) was intended to provide first-order dating of the magnetic-anomaly sequence, thereby resolving much of the uncertainty in the timing of seafloor spreading here.

\footnotetext{
${ }^{1}$ Svrivastava, S. P., Arthur, M., Clement, B., et al., 1989. Proc. ODP, Sci. Results, 105: College Station, TX (Ocean Drilling Program).

2 Geological Survey of Canada, Atlantic Geoscience Centre, Bedford Institute of Oceanography, Dartmouth, Nova Scotia B2Y 4A2, Canada.

3 Graduate School of Oceanography, University of Rhode Island, Narragansett, RI 02882 .
}

The Baffin Bay site was located on the lower slope of Baffin Island margin (Fig. 1) in about $2000 \mathrm{~m}$ of water. The objectives here were to penetrate and recover early post-rift sediments, assumed originally to be Upper Cretaceous-Paleogene in age, to obtain information about their age, and to constrain the basinal subsidence history, both of which are critical for deciphering the tectonic history of this region.

The Labrador Sea and Baffin Bay presently serve as a conduit for the exchange of Arctic and Atlantic waters (Gradstein and Srivastava, 1982), and may have done so since the Late Cretaceous. However, the exact configuration and paleobathymetric regime of this ocean seaway are not well known because of the lack of paleontological information from the deeper part of these basins and also because their tectonic evolution is not well established. Thus, knowledge of the timing of formation and subsidence of these basins is crucial to models of paleoclimate and paleocirculation for the Atlantic and Arctic oceans. Two holes in the Labrador Sea and one in Baffin Bay were drilled to establish the history of development of this seaway.

This study summarizes the drilling results from Leg 105 and the constraints they provide on the tectonic evolution of the Labrador Sea and Baffin Bay.

\section{STRUCTURAL FRAMEWORK}

Before discussing the drilling results and their implications to the tectonic evolution of the Labrador Sea and Baffin Bay, we briefly review the crustal structures of these regions.

\section{Labrador Sea}

Detailed gravity, magnetic, and seismic measurements in the Labrador Sea show that it was formed by seafloor spreading (Srivastava et al., 1981). The best evidence for this comes from the detailed magnetic measurements (Fig. 2). Well-developed magnetic anomalies, resembling those formed by seafloor spreading, lie in most of the Labrador Sea. The resulting pattern of magnetic lineations, as obtained by correlating anomalies between ship's track lines, shows the presence of two groups of lineations. The older group of lineations, containing anomalies older than 24 , lie at an angle to and on either side of a younger group of lineations that contain anomalies younger than 24 . The angle between them increases gradually to the south, signifying a drastic change in the direction of spreading after anomaly 25 (e.g., Chron C25, $59 \mathrm{Ma}$; Berggren et al., 1986a, 1986b). This is also visible from the changes in the directions of the 


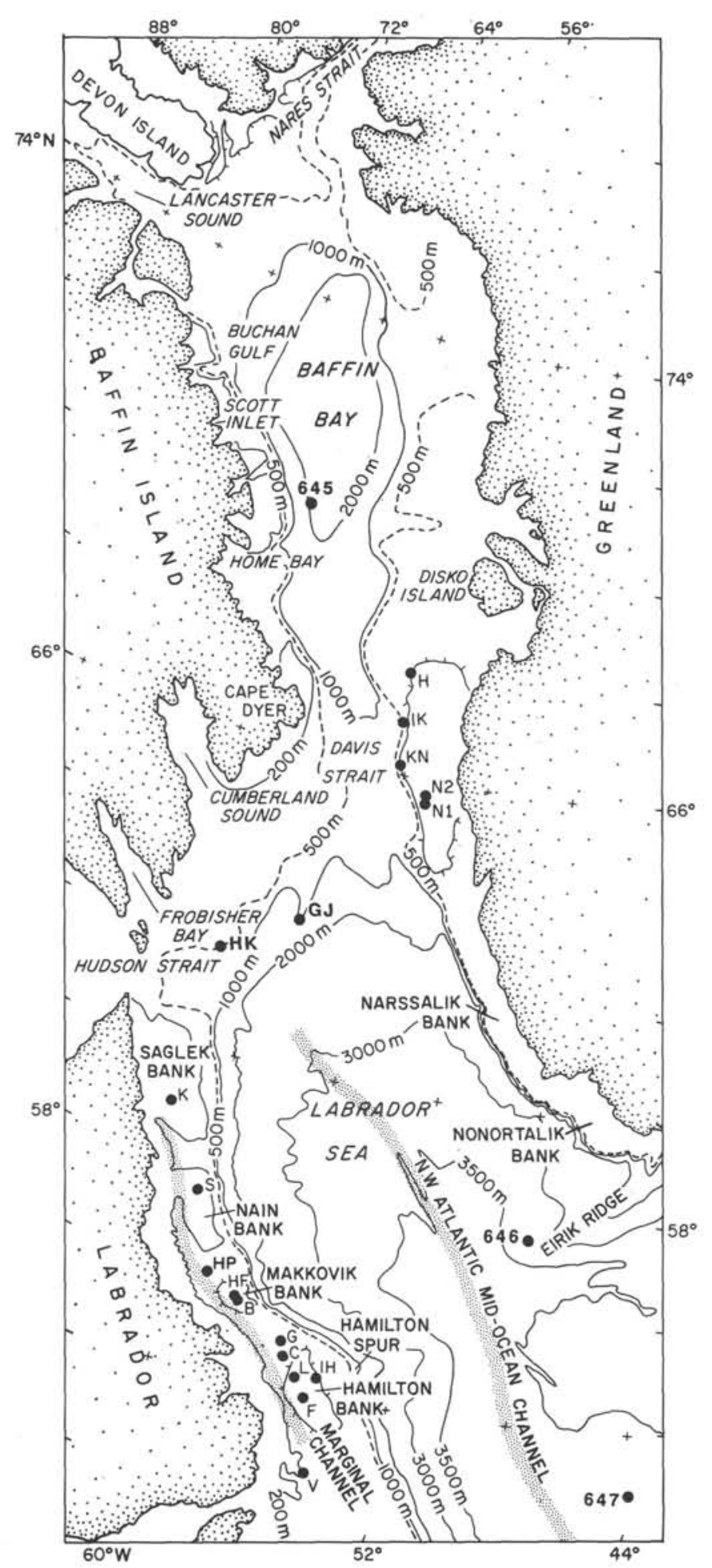

Figure 1. Generalized bathymetry of the Labrador Sea-Baffin Bay region, showing exploratory wells and Sites 645,646 , and 647, drilled during Leg 105. Karsefni (K), Snorri (S), Hopedale (HP), Herjolf (HF), Bjarni (B), Gudrid (G), Cartier (C), Lief (L), Indian Harbour (IH), Freydis (F), Verrazano (V), Nukkik1 (N1), Nukik2 (N2), Kangamiut (KN), Ikermiut (IK), Hellefisk (H), Hekja (HK), and Gjoa (GJ) industry wells also shown. fracture zones. It was at this time that active spreading between Greenland and Eurasia began (Talwani and Eldholm, 1977). In the northern part of the Labrador Sea, the anomalies are subdued in amplitude and the pronounced lineation pattern that exists in the south disappears. Scientists have suggested that this is caused by the obliqueness in the direction of spreading relative to the ridge axis (Roots and Srivastava, 1984).

The spreading between North America and Greenland seems to have started during the Late Cretaceous magnetic normal polarity interval, about $92 \mathrm{Ma}$ ago, with the formation of anomaly 34 in the south Labrador Sea (Srivastava and Roest, 1989). It is difficult to establish when the motion between Greenland and North America stopped from the anomaly pattern, but the northeastward continuation of anomaly 13 southeast of Greenland, as identified by Kristoffersen and Talwani (1977), implies that motion must have ceased at about anomaly 13 (Chron C13, 36 Ma; Berggren et al., 1986a, 1986b).

The position of the extinct axis, as obtained from the correlation and identification of magnetic anomalies, agrees with that obtained from seismic reflection and gravity measurements. A large negative gravity anomaly lies over the extinct ridge axis (Fig. 3), seen as a large rift valley in the seismic-reflection profiles (Fig. 4). In the northern Labrador Sea, where the rift valley is less distinct, the gravity anomaly (Fig. 3) swings to the northwest before trending north-northeast/south-southeast along the Hudson Fracture Zone. We are not certain where the extinct ridge axis lies in the Davis Strait region.

\section{Davis Strait}

Davis Strait is a constricted passage of water that lies between the coasts of southern Baffin Island and west Greenland (Fig. 1). The sill that forms the main part of the strait separates the deeper water of Baffin Bay to the north from that of the Labrador Sea to the south and thus acts as a barrier to the deepwater circulation between the two. The question we wanted to answer concerned the role this sill has played in the exchange of water masses between these two deep basins. Although no holes were drilled on this sill during Leg 105 to answer this question directly, we hoped that by combining the drilling results from Baffin Bay and the Labrador Sea sites we would be able to determine when this sill subsided enough to allow an exchange of water between the two basins.

The problem in estimating the subsidence history of this sill arises from lack of knowledge about the nature of the crust that underlies it. In spite of the large amount of geological and geophysical data for this region, we have not been able to resolve this question. The difficulty lies in deciding whether the region is underlain by true oceanic crust formed by seafloor spreading when Greenland separated from Baffin Island, or by thinned continental crust subsequently modified by the intrusion of basaltic rocks during the Tertiary. Large volumes of Paleocene basalt lie on and off Baffin Island and the west Greenland coasts bordering Davis Strait (Clarke, 1977). The geochemistry of these basalts suggests that they are within-plate-basalt (WPB), except for the early basalt from Baffin Island (Clarke et al., this volume). The shoaling of the sea from the Labrador Sea toward Davis Strait and the affinity of the basalts with WPB strongly suggest that a hot spot, similar to that present now under Iceland, may have been resposible for basalt eruptions and sill formation under Davis Strait (Hyndman, 1973), mainly in the Late Cretaceous-early Paleocene.

Seismic-velocity measurements are suggestive, but not conclusive, that the entire sill is oceanic in nature (Srivastava et al., 1981). The thicker-than-normal, "oceanic" crust (on the basis of velocity, Keen and Barret, 1972) is similar to that observed under Iceland, and supports the hypothesis of a hot-spot origin for this sill. 


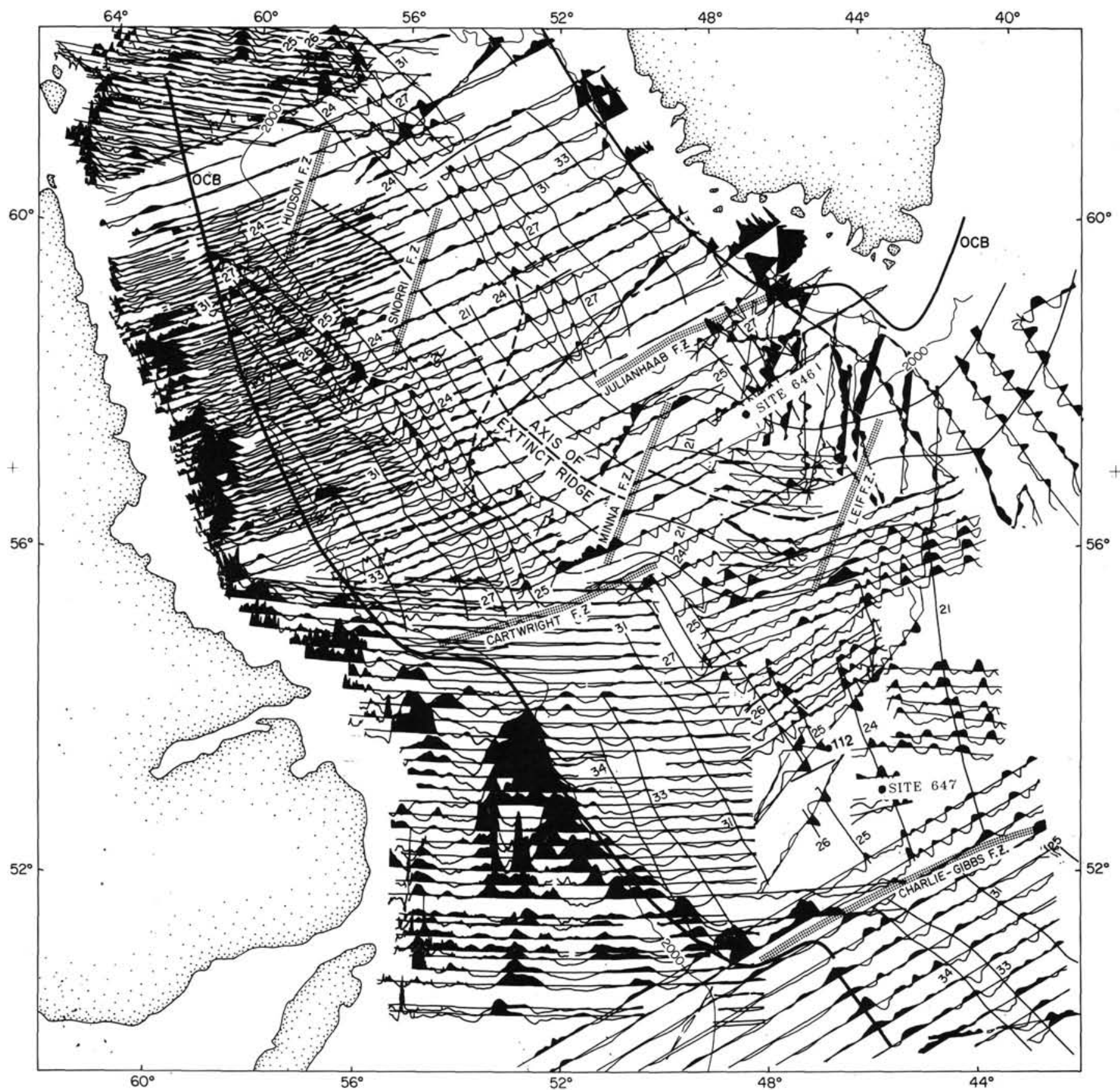

Figure 2. Correlation of seafloor-spreading-generated magnetic anomalies in the Labrador Sea (from Roest and Srivastava, 1989). Shown also are ODP Sites 646 and 647 and DSDP Site 112.

The gravity, magnetic measurements (Figs. 5 and 6), and depth to basement (Fig. 7) in this region show a pronounced north-northeast structural fabric. This is consistent with the direction of motion as required by the plate-kinematic models for the opening of the Labrador Sea (e.g., Srivastava and Roest, 1989). According to these models, the extensional motion before Chron C24 time changed to mainly shearing motion along a north-south direction at Chron $\mathrm{C} 24$ and continued in this direction until the spreading stopped just before Chron $\mathrm{C} 13$ time. Thus, the modified continental or true oceanic crust in this region may have broken up into small blocks, giving rise to a complex structural pattern (like rombochasm), as mapped by Klose et al. (1982) and Srivastava et al. (1982).
The magnetic measurements show large-amplitude, high-frequency anomalies (Fig. 5) typical of those usually observed over volcanic rocks, rather than seafloor-spreading anomalies. Thus, overprinting of extensional structures during Eocene shearing motion makes the palinspastic restoration of the Davis Strait area a difficult task. However, if extensive thinning and segmentation of continental crust are accounted for, problems of apparent overlap in plate reconstruction possibly can be eliminated (e.g., see Srivastava et al., 1982, and Srivastava, 1983).

\section{Baffin Bay}

Unlike the Labrador Sea, the evolution of Baffin Bay is poorly constrained because of the lack of high-density mag- 


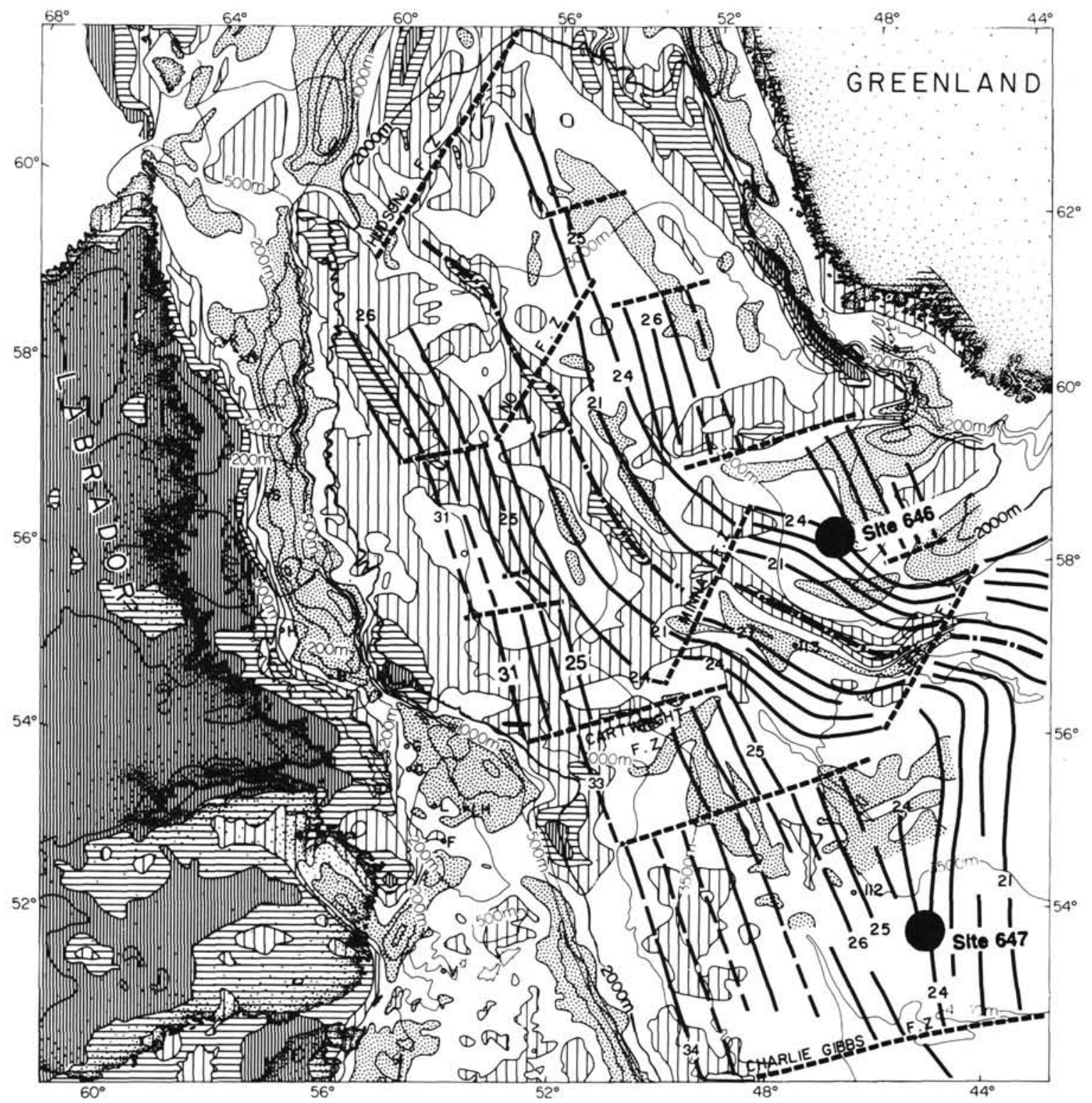

Figure 3. Patterns of magnetic lineations and gravity anomalies near ODP sites in the Labrador Sea. Bathymetry in meters.
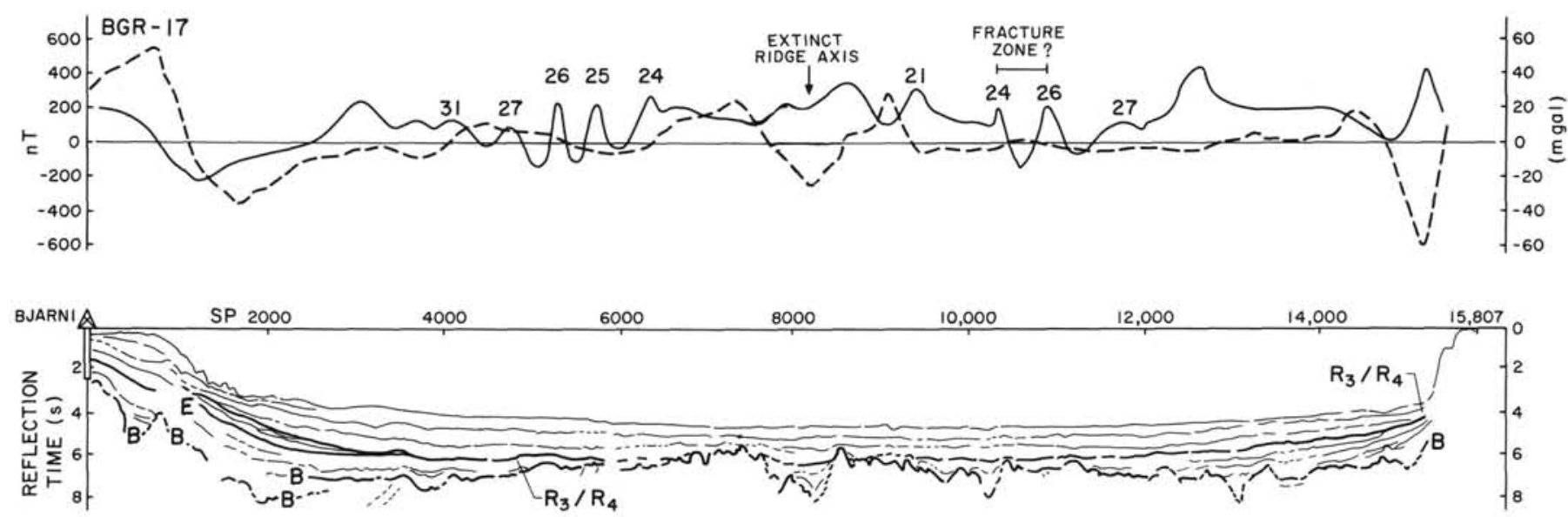

Figure 4. Line drawing of BGR multichannel line 17 in the Labrador Sea. Shown also are the gravity (dotted line) and magnetic anomalies along this line. B refers to basement, E to an Eocene reflector, and R3/R4 to a late Miocene reflector drilled at Site 646. 


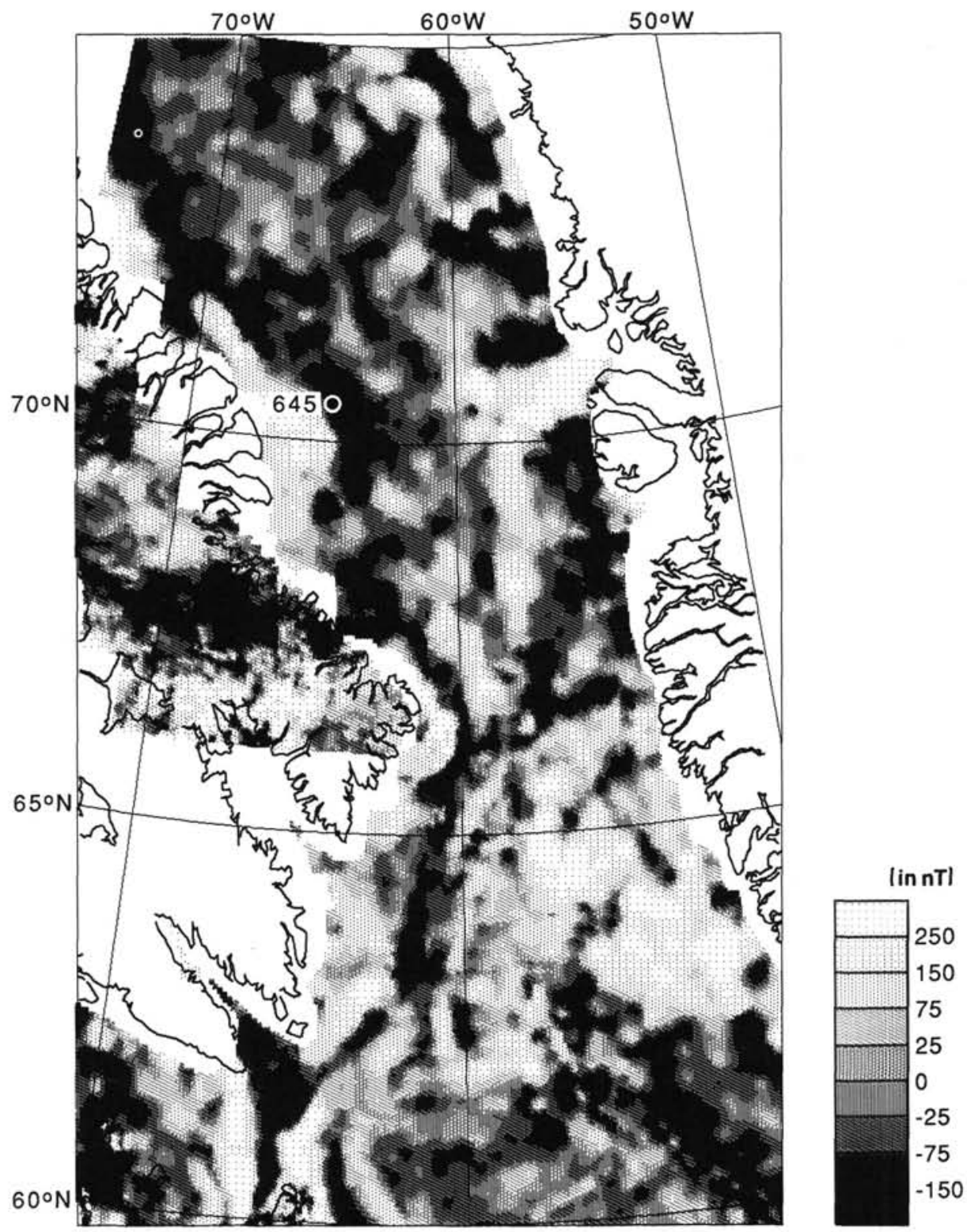

Figure 5. Magnetic anomalies in Davis Strait and Baffin Bay obtained from gridded data. Shown also is Site 645 in Baffin Bay.

netic, gravity, and seismic data throughout the bay. The sparse magnetic data (Fig. 5) fail to show the presence of well-defined, seafloor-spreading-type, magnetic anomalies like those observed in the central Labrador Sea. On the other hand, if the Labrador Sea was formed during the separation of Greenland from North America by seafloor spreading, then the plate geometry, which in this case remains the same, demands that the same must be true for Baffin Bay, unless the plate involved behaved in a nonrigid manner. Plate-kinematic models for the Labrador Sea (e.g., Srivastava and Tapscott, 1986; Srivastava and Roest, 1989) show that a complex motion history, involving first extension then spreading in a north-south direction, occurred in Baffin Bay during the time when the Labrador Sea was formed. This may be one reason for the confused magnetic pattern in Baffin Bay.

Supporting evidence that Baffin Bay was formed by seafloor spreading comes from a number of sources. Seismic-refraction data throughout the bay (Keen and Barrett, 1972), when combined with detailed gravity and magnetic measurements in the center of the bay (Jackson et al., 1979) and a limited number of seismic-reflection measurements across it (McWhae, 1981; Rice and Shade, 1982), support the formation of the bay by seafloor spreading. The gravity data (Fig. 6) show the presence of a gravity low that is coincident with a grabenlike feature seen in one of the multichannel seismic lines shot in this region (McWhae, 1981; Srivastava et al., 1981). This gravity low is probably associated with the axis of an extinct ridge in this region, similar to that observed in the Labrador Sea. The low does not form a continuous feature but is broken into segments, most likely resulting from the oblique motion between plates in this region (Srivastava and Tapscott, 1986).

\section{DRILLING RESULTS AND THEIR TECTONIC IMPLICATIONS}

\section{Baffin Bay}

One of the objectives of drilling in Baffin Bay during Leg 105 was to obtain data to test hypotheses for the timing of rifting and possible seafloor spreading in this region. Ideally, this 


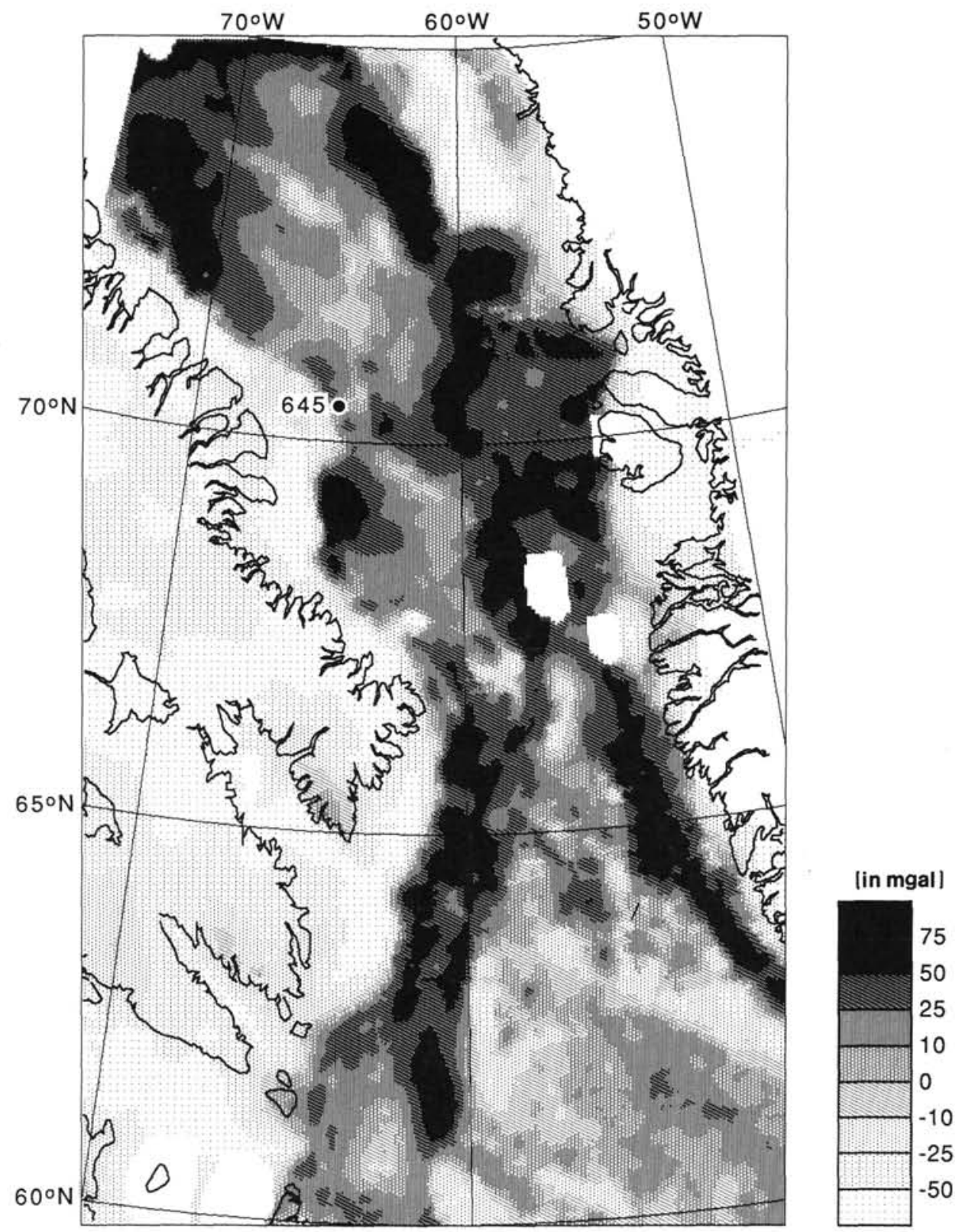

Figure 6. Gravity anomaly map of Davis Strait and Baffin Bay region obtained from gridded data. Also shown is Site 645 in Baffin Bay.

can only be achieved by drilling through the entire sediment column and into the underlying basement. Because basement lies beneath at least 3 to $4 \mathrm{~km}$ of sediments at most places in Baffin Bay (Fig. 7), which could not be drilled within the given time frame, we decided to drill at a site where some of the major seismic reflectors, i.e., those that can be traced across the Bay, could easily be reached. Adequate ages of the major reflectors could then be obtained to provide a calibrated interpretation of the seismic data for timing of tectonic events, subsidence, and sedimentation events in this region.

Thus, Site 645 was chosen, located on the lower slope of Baffin Island in a water depth of $2005 \mathrm{~m}$ (Fig. 1). Examination of a network of multichannel seismic lines in the vicinity of this site shows that basement to the west is down-faulted and covered by a substantial amount of Cretaceous and younger sediments (Fig. 8). Gravity, magnetic (Figs. 5 and 6), and seismic-refraction measurements suggest that the site lies close to the ocean- continent boundary. One of the reflectors, called here R3, can be traced across the entire bay. This is the first major reflector to overlie the extinct ridge axis (which is marked by a central graben in the center of Baffin Bay); thus, we interpret it as marking the cessation of spreading in the bay. One of our objectives at Site 645 was to penetrate and recover strata below this reflector.

In all, seven holes were drilled near Site 645 , the deepest of which reached to a depth of 1147 meters below seafloor (mbsf). The entire sequence recovered at Site 645 had a strong terrigenous character, with sparse microfossils. Because of the scarcity of diatoms, radiolarians, planktonic foraminifers, and calcareous nanoplankton, the ages of various lithological units (Fig. 9) were based on dinoflagellates and benthic foraminifers, which were present throughout most of the section. The oldest sediments reached at this site were lower Miocene or upper Oligocene. Paleomagnetic data furnished additional tie-points with 


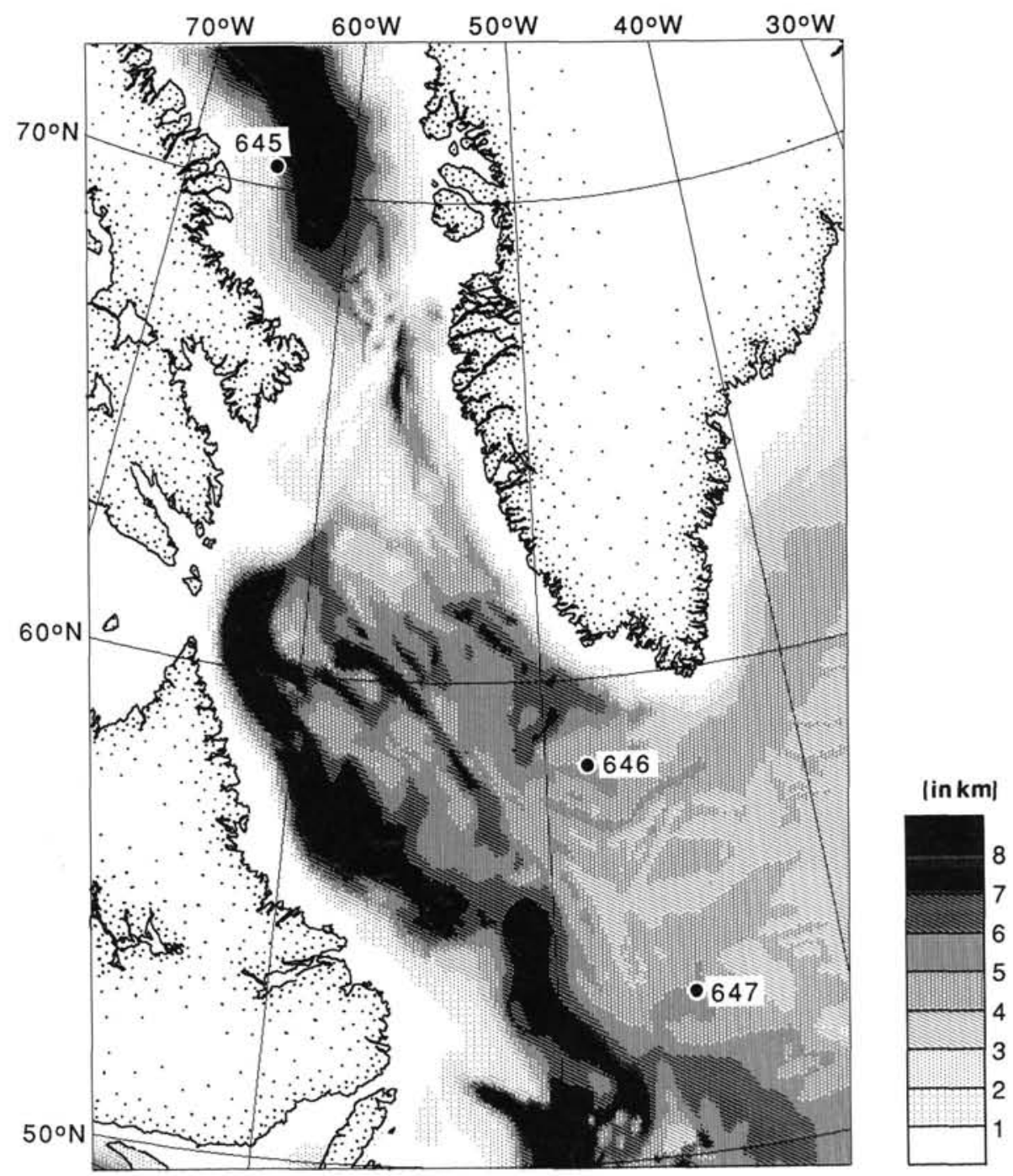

Figure 7. Depth-to-basement map of the Labrador Sea, Davis Strait, and Baffin Bay region compiled by Oakey et al. (1988). The map was obtained by combining the published maps of the Labrador Sea by Srivastava (1986), of the Davis region by Tucholke and Fry (1986), and of Baffin Bay by Grant (1988). Depth in kilometers.

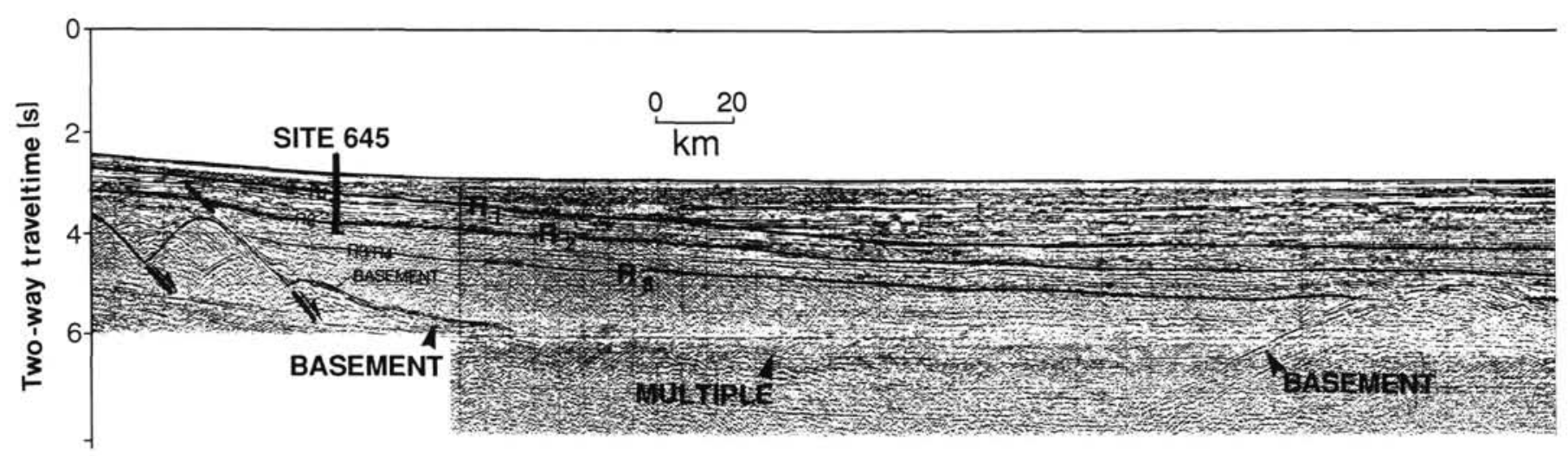

Figure 8. Multichannel line 74-51 across Site 645 showing presence of reflectors R1, R2, and R3. 


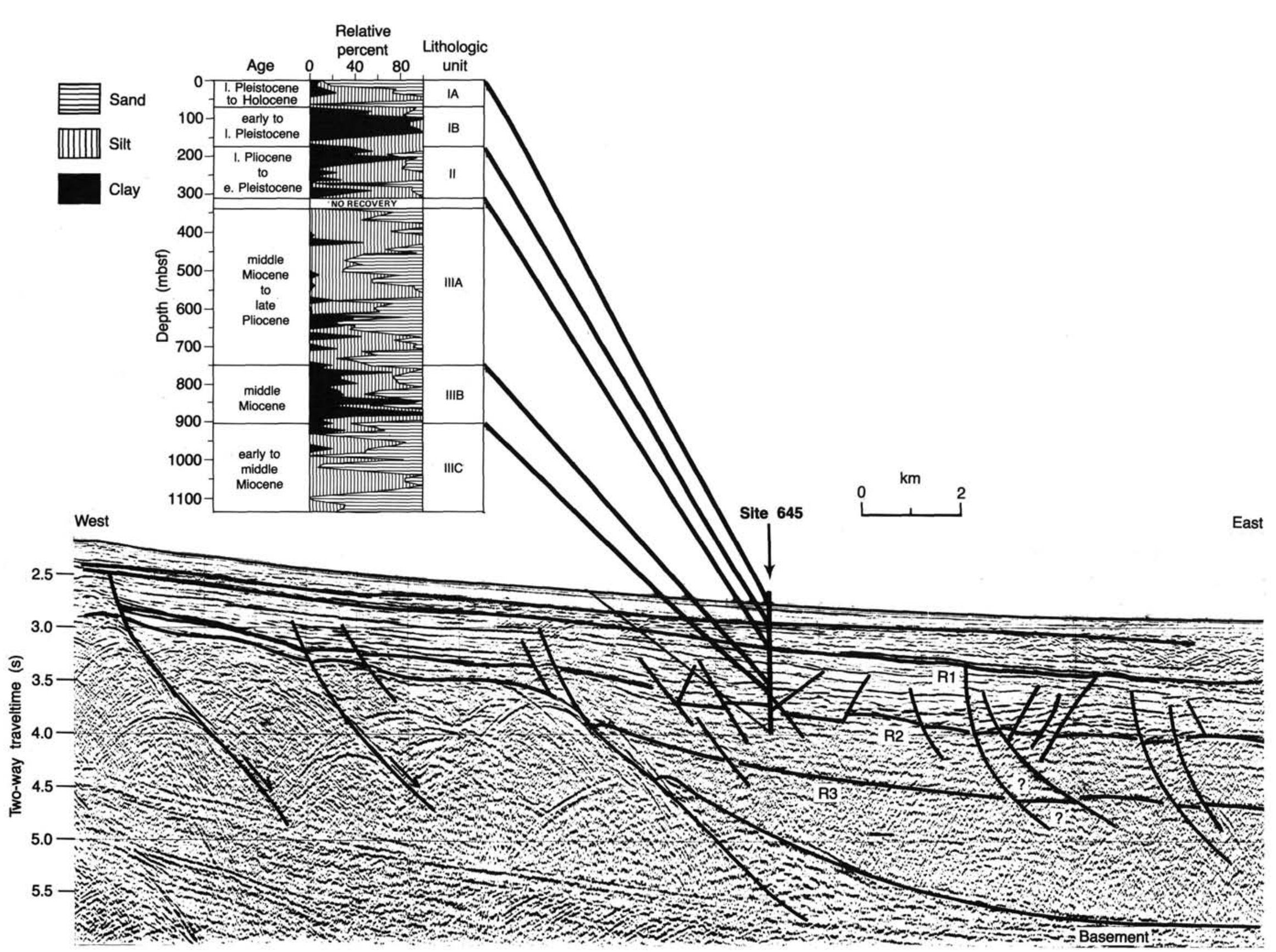

Figure 9. Part of multichannel line 74-51, showing correlation of major reflectors and seismic units to lithology at Site 645 . 
which we were able to construct a sedimentation curve for this site (Fig. 10). The details of the lithologic units and their ages are described in Srivastava, Arthur, et al. (1987).

Based on the lithostratigraphy and the sedimentation rate, we were able to date some of the major seismic reflectors at this site. Reflector R1 (Fig. 9), which signifies a change in depositional style near the early/late Pliocene boundary, is coincident with the beginning of major continental glaciation in this region. The reflector is overlain by a thick wedge of upper Pliocene-Pleistocene "glacial" sediments that prograde from the West Greenland margin (Figs. 8 and 9). Reflector R2 is an erosional unconformity over part of the region and underlies a package of bottom-current-formed sediments. It is dated as mid-Miocene.

Reflector R3 (at about 1560 mbsf) could not be reached because of time limitations and delays resulting from a series of equipment failures early in the drilling of this site. However, an extrapolation of the sedimentation rate at the bottom of the hole to the level of R3 (Fig. 10) yields an age near the Oligocene/Eocene boundary. This roughly corresponds to the age when seafloor spreading is interpreted to have ceased in the Labrador Sea and Baffin Bay (Srivastava et al., 1981).

Drilling results at Site 645 do not provide the age of the underlying basement to verify some of the tectonic models proposed for this region. However, they do provide valuable information that can be used to see if a seafloor-spreading model is

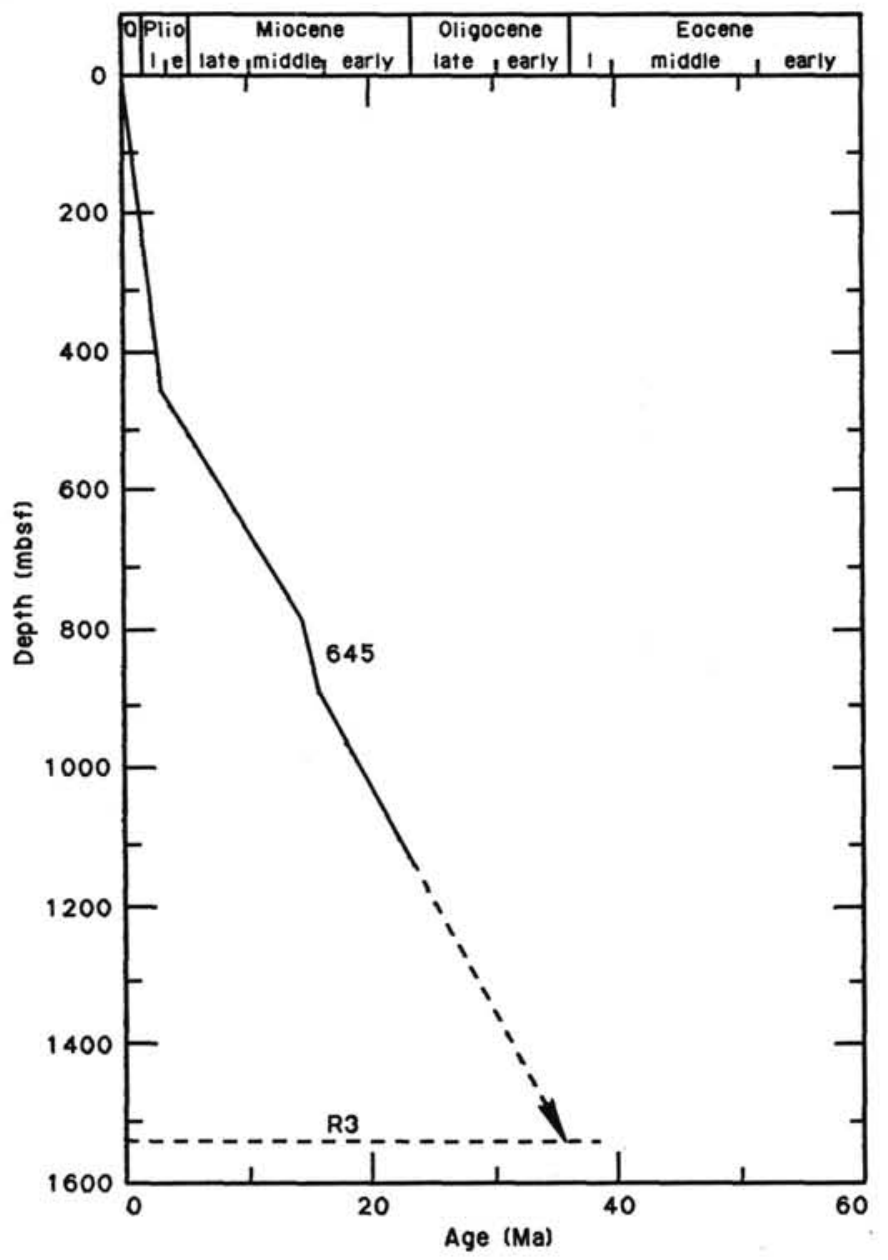

Figure 10. Sedimentation rate at Site 645 . applicable to this region. For example, ages of the seismic reflectors observed in this region are important for understanding the rate of subsidence of this region. If Baffin Bay was formed by seafloor spreading or by crustal stretching, then its margins should show subsidence similar to that observed elsewhere along passive margins. Drilling results from Site 645, together with other subsurface information, were used to study the subsidence history of the western Baffin Bay margin.

Several investigations have been conducted to study the subsidence history of the passive margins (e.g., Watts and Steckler, 1979; Keen, 1979; Issler and Beaumont, 1986). All show that the subsidence of passive margins with time is caused by two factors: the loading effect of the overlying sediments (and water) and the thermal contraction of the underlying lithosphere with time. If the loading effect of the overlying sediments can be removed, then one can isolate that part of the subsidence not caused by sediment loading. To do this, one needs detailed and accurate biostratigraphic and lithologic information. To compute a subsidence history for Site 645 with limited information about the deeper sections, we assumed the following:

1. That the age of the reflector R3 is $36 \mathrm{Ma}$ (Oligocene/Eocene), even though an age of $33 \mathrm{Ma}$ was obtained from the extrapolation of sedimentation rate at Site 645 . Considering the long range of species used to derive the average rate of sedimentation, the difference is not excessive.

2. That the age of the oldest sediments overlying the basement is not greater than $72 \mathrm{Ma}$ and is less than $55 \mathrm{Ma}$. This is based on the assumption that the sedimentation rate between reflector R3 and the basement is similar to or higher than observed for the overlying sequence. The older $(72 \mathrm{Ma})$ assumed age of the sediments roughly corresponds to what scientists believe is the initiation of seafloor spreading in Baffin Bay region (Srivastava and Tapscott, 1986). On the other hand, the younger age corresponds to ages of basalt flows on West Greenland and southern Baffin Island (Clarke, 1977).

3 . That the densities and porosity values in the deeper part of the section at Site 645 can reasonably be estimated from the extrapolation of those observed in the overlying sections. The porosity values measured on discrete samples show a gradual decrease with increasing depth, while density values do not show any systematic variations with depth (Srivastava, Arthur, et al., 1987).

Based on the above assumptions and using the backstripping method of Watts and Steckler (1979) and Issler (1987), we were then able to calculate the loading effect of the overlying sediments and water column at Site 645 . These calculations were performed by assuming an Airy isostatic compensation model. In our calculations we used the density and porosity values obtained from shipboard measurements on discrete samples (Srivastava, Arthur, et al., 1987). The porosity values were fitted with linear expressions, although others have used exponential expressions (e.g., Busch, this volume). A comparison of the porosity values obtained by the two expressions showed little difference between the two. The resulting subsidence (Fig. 11) shows that since early Oligocene the rate of "tectonic" (unloaded basement) subsidence of the crust under Site 645 has been exponential, similar to that expected from a thermal-contraction hypothesis, when spreading ceased at that time. The rate of subsidence before $36 \mathrm{Ma}$ is not well constrained and several possibilities exist for it, as shown here, based on the ages assigned to the oldest sediments overlying the basement. We have assumed that at the time of initial rifting or seafloor spreading, the basement at Site 645 was at about sea level. We favor the $63 \mathrm{Ma}$ age, as it more or less lies between the two extreme ages and fits the exponential trend better. 


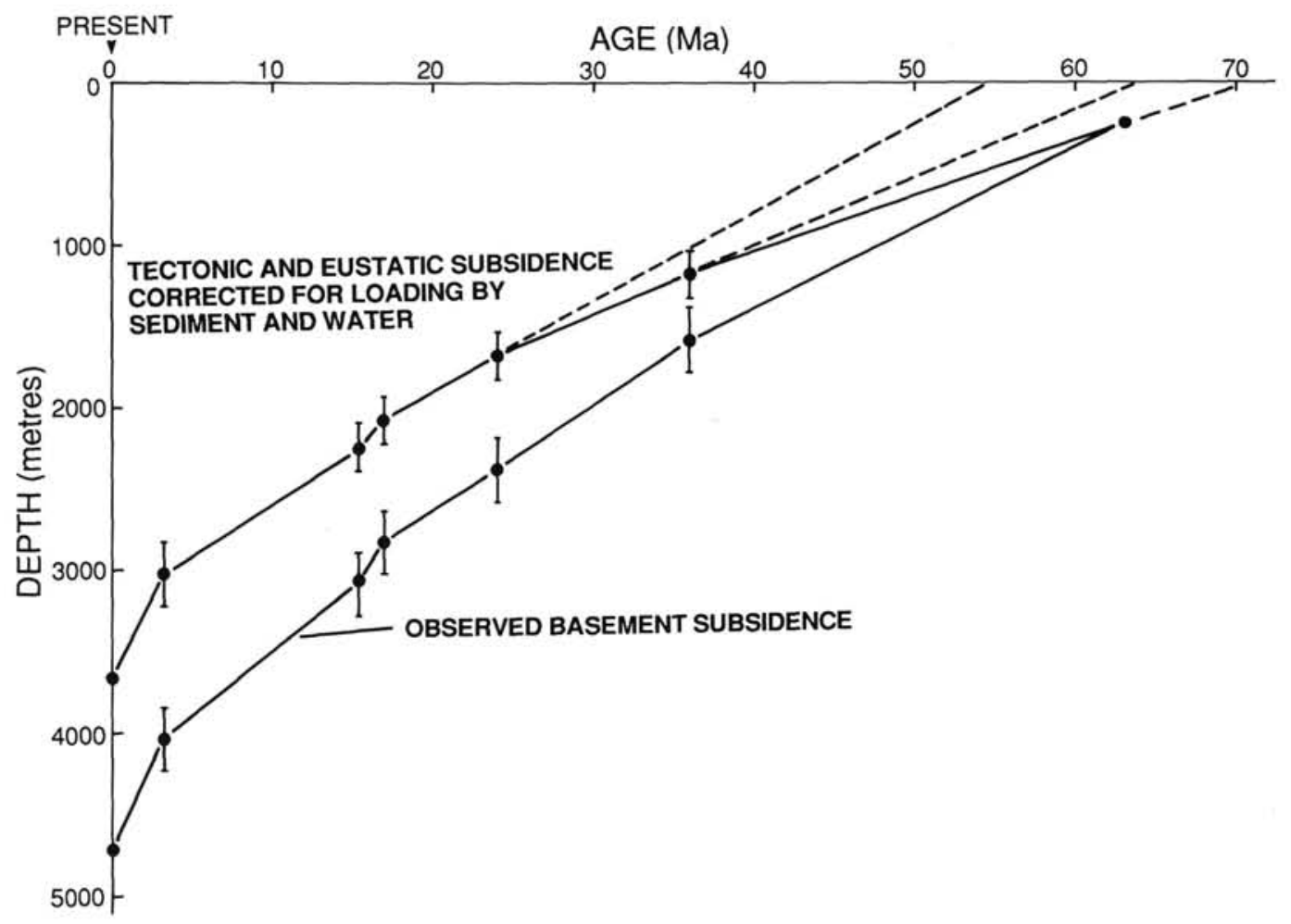

Figure 11. Plot of observed basement subsidence and corrected subsidence for sediment-loading effect. Estimate of average paleodepths used are as follows: $0 \mathrm{Ma}, 2020 \mathrm{~m} ; 3.4 \mathrm{Ma}, 1600 \mathrm{~m}( \pm 200 \mathrm{~m}) ; 16.5 \mathrm{Ma}, 750 \mathrm{~m}( \pm 200 \mathrm{~m})$; $36 \mathrm{Ma}, 450 \mathrm{~m}( \pm 150 \mathrm{~m})$.

Another way of looking at the rate of subsidence is to plot it vs. the square root of $t$ since the time of initiation, which is shown in Fig. 12. This indicates that subsidence varies linearly with the square root of time, a behavior expected for a thermally cooling lithosphere. The sharp break at Chron C13 may not be real, as it mainly arises from the lack of data prior to this time.

We do realize that a number of assumptions had to be made in deriving this subsidence curve for Site 645 and that the actual subsidence may differ somewhat from the one obtained here. The calculations show that, at least since the Oligocene, the rate of subsidence has been similar to that expected for a thermally cooling lithospheric plate. We cannot, however, deduce for certain when this subsidence started to take place, but extrapolation of this trend suggests it may have been about $63 \mathrm{Ma}$ ago. Such an age is in good agreement with the plate-kinematic solution for this region (Srivastava and Tapscott, 1986).

\section{Labrador Sea}

Drilling was conducted at two sites in the Labrador Sea during Leg 105: at Site 646, located southwest of Greenland on the northern flank of a sediment drift deposit known as Eirik Ridge, and at Site 647 in the southern Labrador Sea, located north of the Charlie-Gibbs Fracture Zone and on the southwestern flank of another drift deposit known as Gloria Drift (Fig. 1). Only one of these holes (Site 647) penetrated the basement rock, while at the other hole (Site 646), only late Miocene to Holocene strata were recovered.

Drilling into the basement rock at Site 647 was planned to obtain its age so that the overlying magnetic anomaly could be dated and thereby constrain the tectonic model for this region. A previous attempt (Laughton et al., 1972) to date one such

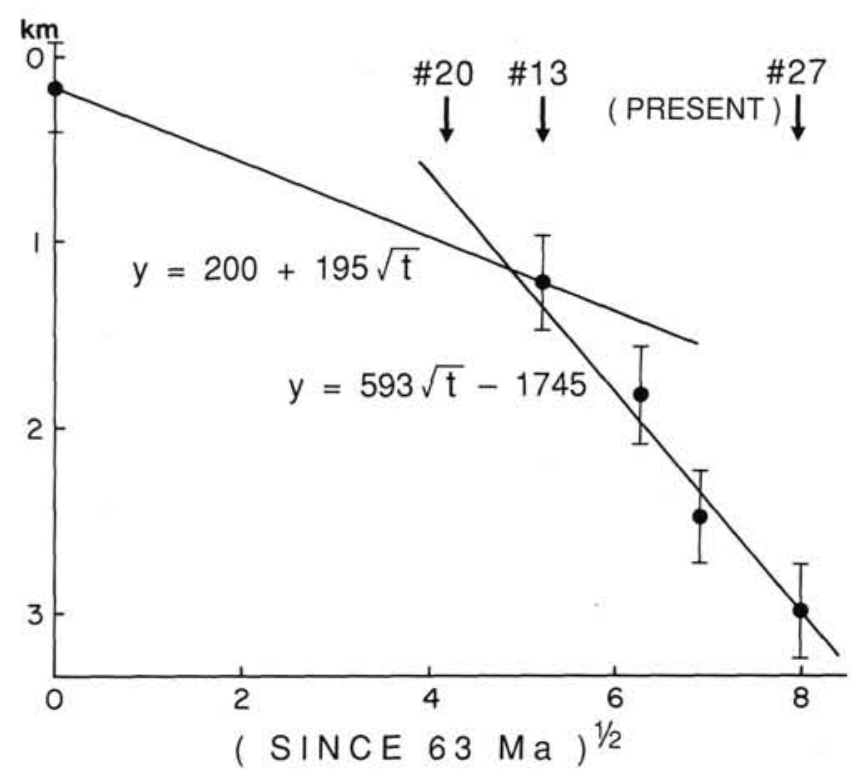

Figure 12. Plot of basement subsidence vs. square root of age since the time of rifting, calculated as $63 \mathrm{Ma}$.

anomaly by drilling on a basement high on suspected anomaly 26 crust (DSDP Site 112) resulted in obtaining a weathered section of basalt for which no tests for age could be performed. The sediments immediately overlying the basalt were devoid of microfossils and, therefore, could not provide a minimum age for the underlying basement rocks. 


\section{Site 647}

Site 647 was located in a region where magnetic anomalies are well developed and can easily be correlated between tracks (Fig. 13). The site lies slightly west of anomaly 24B. The Neogene sediments at this site are fairly thin, which allowed for quick penetration into the underlying Paleogene sediments and basement.

A 736-m-long section consisting of $699 \mathrm{~m}$ of sediments and $37 \mathrm{~m}$ of basalt was drilled at Site 647 . The entire sedimentary section was found to be rich in planktonic and benthic foraminifers, calcareous nannofossils, diatoms, and radiolarians, thus providing numerous biostratigraphic datums for calculating the rate of sedimentation at this site. Based on this and paleomagnetic measurements on discrete samples, we were able to obtain a sedimentation rate for this site (Fig. 14). Two of the prominent reflectors were dated. Reflector R2, which lies at the base of seismic Unit 1 (Fig. 15), corresponds to a 3-Ma hiatus separating upper Pliocene (2.5 Ma) from upper Miocene (5.6 Ma) sediments. The exact age of this reflector cannot be determined because another hiatus between the 8.2- to 17.5-Ma interval lies 3 $\mathrm{m}$ below the previous hiatus. Another major reflector, R4 of early Oligocene age, lies within a high sedimentation-rate sequence and corresponds to a lithologic change from siliceous sediments above to calcareous sediments below. The reflector appears to bear no direct relationship to changes in bottom-water circulation at this site, contrary to Miller and Tucholke's suggestion (1983), based on their analysis of data from nearby DSDP Site 112 .

About $37 \mathrm{~m}$ of fine- to medium-crystalline, aphyric to phyric basalt, representing one or more flows, was recovered at the base of the hole. The fresh appearance of the basalt recovered and the absence of interbedded sediments suggest that it represents the top of layer 2 . Fossiliferous sediments immediately overlying the basement contained calcareous nannofossils of early Eocene age (NP11). Dinoflagellates recovered slightly above this level corroborate this age, and both microfossil groups restrict the age for the oldest sediments to 55-56 Ma. This age agrees well with the predicted age based on the magnetic anomaly identification, and thus supports the tectonic history of the Labrador Sea proposed by Srivastava (1978) and Srivastava et al. (1981).

Radiometric age determinations (potassium/argon) conducted by Roddick (this volume) on a few of the basalt samples from this site show a considerable scatter in value (Table 1). Ages range from 35 to $71 \mathrm{Ma}$. The large scatter is due to the low potassium contents and excess atmospheric argon. Roddick suggests that this is perhaps caused by some minor alteration in the basalt samples, producing secondary minerals with poor argon retention. Attempts are being made to use the ${ }^{39} \mathrm{Ar} /{ }^{40} \mathrm{Ar}$ method to see if a better estimate for the age can be obtained, but results are not yet available. Detailed petrological and chemical analyses performed on the samples (for details see Clarke et al., this volume) from the drilled basalt show that they come from a fresh, unaltered basalt.

Considerable evidence of late hydrothermal activity was shown by the presence of hydrothermal quartz and calcite in the sediments directly overlying the basement rocks. Evidence of faulting and fracturing was seen in Eocene-age strata overlying the basement to depths as shallow as 250 mbsf in the cores (Srivastava, Arthur, et al., 1987). Evidence of faulting occurs only in strata older than early Oligocene.

Faulting is also evident in the seismic lines near the site (Fig. 15) and may affect strata at and below reflector R4. Most likely, this deformation in the sediments is caused by the differential basement subsidence, which prevailed until seafloor spreading ceased and sediments covered the area without deformation after the early Oligocene. This deformation possibly may have

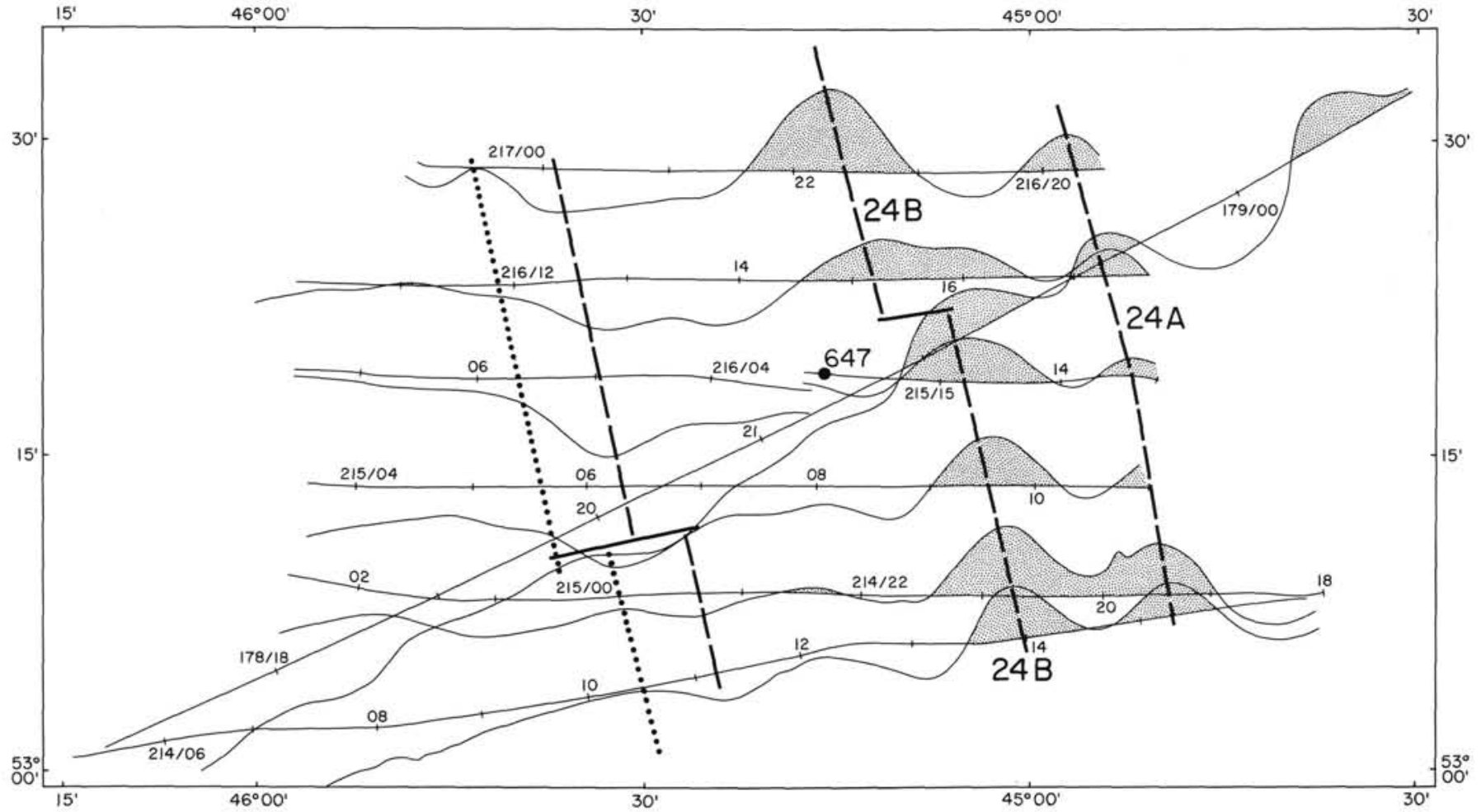

Figure 13. Magnetic anomalies plotted along track lines showing their correlations near Site 647 . The dotted line marks a change in basement character from smooth to rough (Srivastava et al., this volume). 


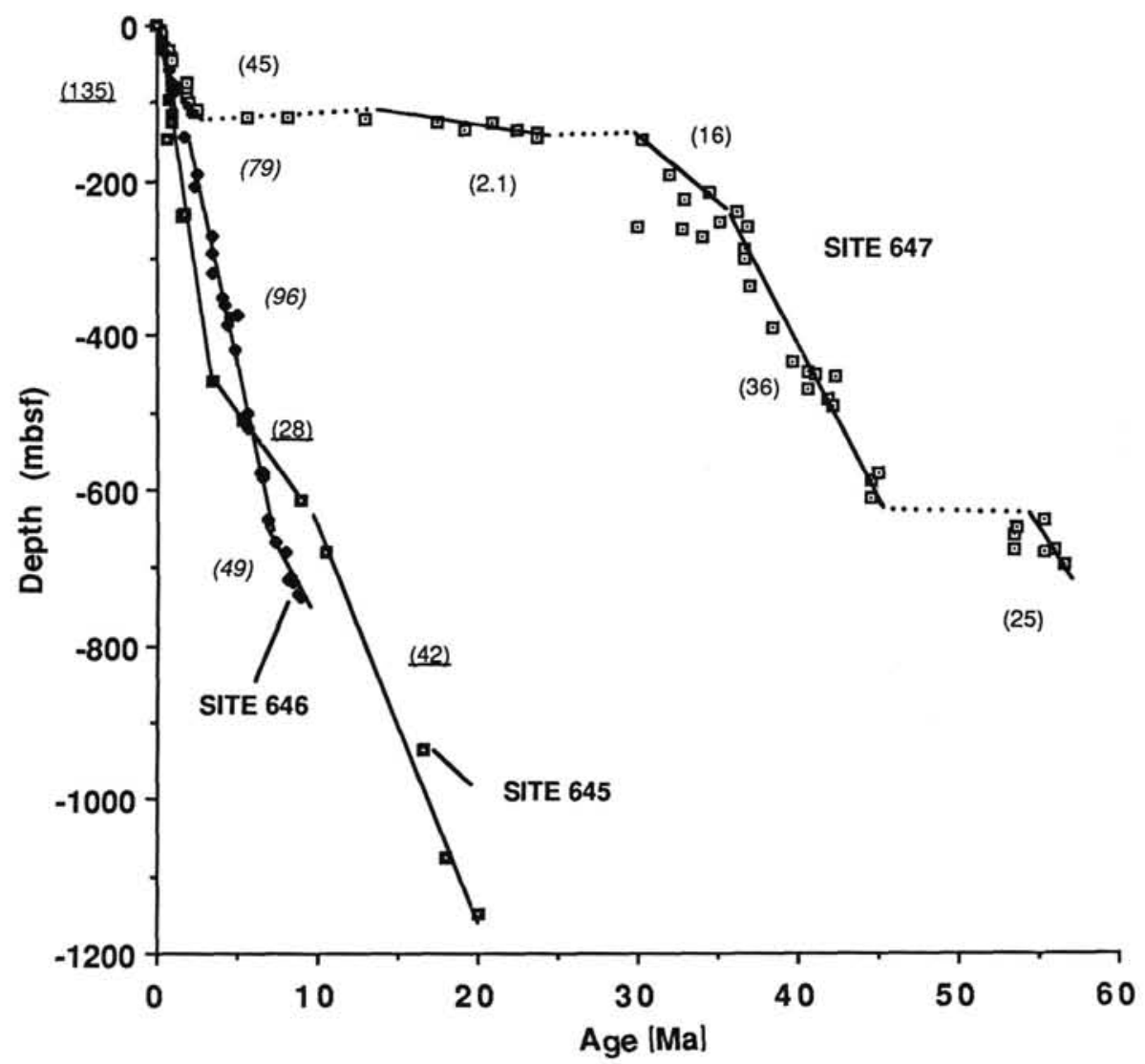

Figure 14. Rates of sedimentation at Sites 646 and 647.

been caused by some secondary tectonic event, but according to the plate-tectonic model for this region (Srivastava, 1978), the only tectonic event that took place in this region was before anomaly 24 .

\section{DISCUSSION}

Drilling results from Leg 105 , as summarized above, clearly show that the crust under Site 647 in the Labrador Sea is oceanic in nature and that the basement at Site 645 in Baffin Bay has been subsiding at a rate, at least since the Oligocene, similar to that expected from a thermally cooling lithosphere. Both of these results thus support the interpretation, based on synthesis of regional geological and geophysical data, that the Labrador Sea and Baffin Bay evolved by seafloor spreading.

The age of the crust under Site 647 , as obtained from the overlying sediments, fits remarkably well with the age of the magnetic anomaly at this site, although radiometric age determinations show a lower value. The lower value obtained from the radiometric determination is not surprising, considering that excessively low potassium was detected in most of the samples analyzed (Roddick, this volume). The possibility that these lower ages are indicative of younger volcanic rocks that may overlie the older basalts at the site can be ruled out because the overlying sediments do not show evidence of baking or post-depositional alteration. Furthermore, chemical analysis performed on the basalts from this site failed to show definite evidence for the presence of more than one flow (Clarke et al., this volume). The age of the crust and its basaltic nature at this site thus argue strongly for the formation of the Labrador Sea by seafloor spreading.

It is now well established that as new oceanic crust forms and cools, it subsides with time (Parson and Sclater, 1977). Thus, a relationship exists between the age of the ocean floor and its depth. Considering that our drilling results and regional data show clearly that the Labrador Sea was formed by seafloor spreading, we should be able to see if a similar relationship also applies here. We find that the average water depth at Site 647 is $800 \mathrm{~m}$ shallower than the world average for seafloor of that age $(56 \mathrm{Ma})$. We find the same thing at other places in the Labrador Sea, based on the identifications and location of magnetic anomalies. Thus, the ocean floor in most of the Labrador Sea is shallower by about $1 \mathrm{~km}$ than the world average for its age.

The ocean floor gets even shallower as we approach Davis Strait sill (Fig. 7). Such a behavior of the ocean floor led Hyndman (1973) to suggest that it may be caused by the compositional differences in the lithosphere structure, due to the presence of a hot spot under Davis Strait during Paleocene time. If this is true, the detailed geochemical examination conducted on the basalt samples and the heat flows measured at the drilled sites should be helpful in finding answers to this problem. These are briefly described below.

\section{Labrador Sea}

\section{Basalts from Site 647}

Clarke et al. (this volume) have conducted a detailed analysis on basalt samples from this site and found that it contains olivine- to quartz-normative tholeiitic basalts that are highly depleted in incompatible trace elements. According to them, these basalts are similar to mid-ocean ridge basalts (MORB). Clarke et al. further found that these basalts are very similar, in terms of incompatible trace elements, to the terrestrial Paleocene basalts on Baffin Island, although the two differ in their strontium-neodymium isotope systematics. Based on their findings, 


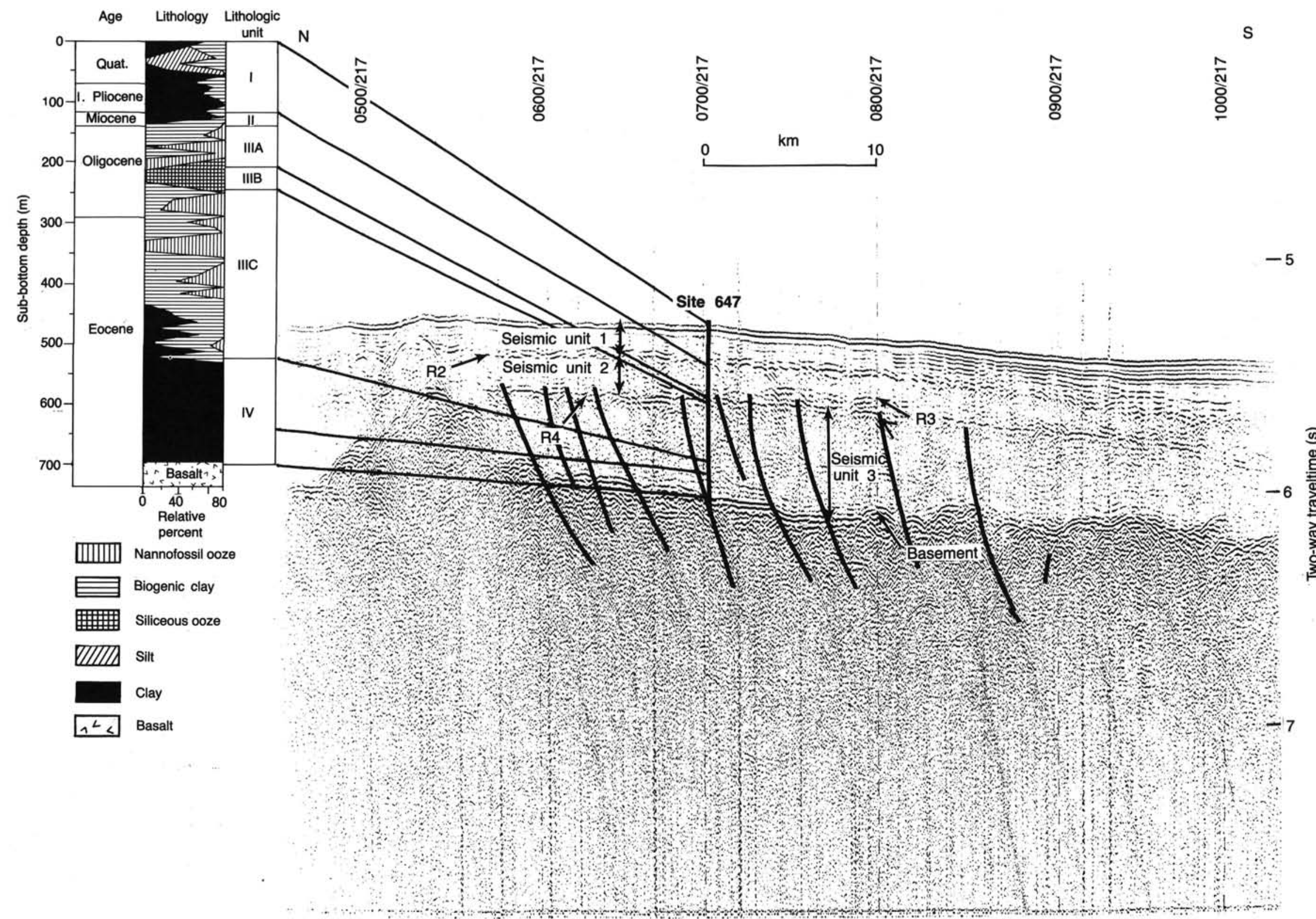


Table 1. Potassium-argon data for Site 647 from whole-rock basalts.

\begin{tabular}{|c|c|c|c|c|c|c|}
\hline $\begin{array}{l}\text { Core, section, } \\
\text { interval }(\mathrm{cm})\end{array}$ & $\begin{array}{l}\text { Depth } \\
\text { (mbsf) }\end{array}$ & $\begin{array}{l}\text { Lab } \\
\text { no. }\end{array}$ & $\begin{array}{c}K(w t \%) \\
( \pm 1 \sigma \%)\end{array}$ & $\underset{\left(\mathrm{cm}^{3} / \mathrm{g} 10^{-7}\right)}{\operatorname{Rad}^{40} \mathrm{Ar}}$ & $\begin{array}{l}\% \text { Atmos. } \\
\left.\text { ( }{ }^{40} \mathrm{Ar}\right)\end{array}$ & $\begin{array}{c}\mathrm{Age} \pm 2 \sigma \\
(\mathrm{Ma})\end{array}$ \\
\hline \multicolumn{7}{|l|}{$105-647 \mathrm{~A}$} \\
\hline $72 \mathrm{R}-1,9-11$ & 704 & 3778 & $0.0294 \pm 2.2$ & 0.5242 & 94.2 & $45.3 \pm 4.3$ \\
\hline $72 \mathrm{R}-3,9-10$ & 707 & 3779 & $0.0325 \pm 2.0$ & 0.9109 & 95.2 & $70.7 \pm 11$ \\
\hline $72 \mathrm{R}-4,10-11$ & 709 & 3781 & $0.0321 \pm 1.5$ & 0.4366 & 92.8 & $34.7 \pm 12$ \\
\hline $73 R-4,99-101$ & 719 & 3777 & $0.0236 \pm 3.0$ & 0.6259 & 97.8 & $67.0 \pm 13$ \\
\hline $74 \mathrm{R}-2,25-32$ & 725 & 3776 & $0.0499 \pm 1.8$ & 0.7580 & 95.0 & $38.7 \pm 4.1$ \\
\hline $74 \mathrm{R}-2,32-35$ & 725 & 3780 & $0.0488 \pm 1.5$ & 1.1770 & 98.0 & $61.0 \pm 12$ \\
\hline $75 R-4,49-52$ & 736 & 3775 & $0.0503 \pm 2.9$ & 0.9222 & 96.5 & $46.6 \pm 6.7$ \\
\hline
\end{tabular}

Clarke et al. suggest that the Site 647 and early Baffin Island basalts were derived from a similar depleted source mantle composition. However, the later lavas from Baffin Island, and possibly all lavas from West Greenland, according to them, were generated from a more enriched mantle. They attributed strontiumisotopic composition of Site 647 basalts to the interaction with seawater. On a tectonic discrimination diagram, the early Baffin Island basalt and those from Site 647 fall within the MORB or Ocean Floor Basalt (OFB) field, while those from West Greenland and later lavas of Baffin Island fall mainly into the Within Plate Basalt (WPB) field. The similarities and differences in the incompatible trace elements between Site 647 and Davis Strait basalts are interesting because they perhaps point to the expected variations with distance from a hot spot. Some scientists have suggested that Davis Strait was the site of a hot spot during the Paleocene (Keen and Clarke, 1974; Hyndman, 1975) and that it had migrated to the east, under Greenland by the time of anomaly 24 , when active spreading started between Greenland and Eurasia. The same hot spot now underlies Iceland. Thus, to see if the observed differences in the geochemistry of basalts between Baffin Island and Site 647 could be explained by the presence of a hot spot, we looked at the observed differences between the basalts of Iceland, East Greenland, and those drilled on the western flank of Rockall Plateau. This is described briefly below.

If basalts at Site 647 were influenced by this hot spot, then the same would have been true for the basalts that were coeval to Site 647 basalts and that now lie on the eastern side of the Atlantic. The only drilled basalts of comparable age lie slightly north of Site 647 , on the western margin of Rockall Plateau (Fig. 16).

\section{Basalts from the Western Margin of Rockall Plateau}

During DSDP Leg 81, a number of holes were drilled across the western margin of Rockall Bank (Fig. 16) to sample rocks from the dipping reflectors that occur in this region and also from the outer high. The latter is thought to be related to the initial formation of the oceanic crust in this region (Roberts et al., 1984). Basalts from the dipping reflectors and the outer high were found to consist of submarine and subaerial lava flows. They were oceanic tholeiites depleted in light rare-earth elements (Joron et al., 1984). The basalt from all five holes (except Hole 406, Fig. 16), whether located on the continental or the oceanic side, were almost identical. According to Joron et al. (1984), petrologically and mineralogically these basalts resemble deep-ocean floor basalt, with some peculiarities. The results of major and supplementary trace-element analysis on these basalts showed no progressive change in the volcanism from the basalts overlying the continental crust to those lying in the oceanic domain (Richardson et al., 1984). These authors explain the variations in the zirconium content observed between holes by suggesting that the basalt in this region originated from two magma types, both of which had clear ocean-floor signatures when examined by discrimination diagrams. However, lead-isotope analysis conducted on basalt samples from Hole 403 (Fig. 16), which drilled into the dipping reflectors, shows that these basalts may have been contaminated by ancient uranium-depleted continental crust, or alternatively, derived from a subcontinental lithosphere mantle source (Morton and Taylor, 1987). This implies that the basalt at Site 403 was formed by eruption through and onto continental basement. This is contrary to the results from geochemical analysis performed on samples from all holes drilled on the Rockall Plateau that suggest that these samples were all generated from a similar magma source. Even if the basalts at Site 403 were somewhat contaminated by continental crust, those drilled at Site 404 were not and can be considered as true oceanic basalt, which the geochemical analysis suggests.

A comparative study of the basalts from Rockall, the Faeroes, and East Greenland conducted by Richardson et al. (1984) showed that even though the basalts from these regions erupted at the same time and have similar major-element characteristics, they differ in their trace-element signatures, with Greenland and most of the Faeroes showing WPB affinities and Rockall and later Faeroes showing OFB affinity. This is very similar to what is observed between the Davis Strait and Site 647 basalts. The question then arises, is this what one can expect from the presence of a hot spot? The answer does not seem to be a simple one, because one finds similar variations in the geochemistry even in the Iceland basalt. For example, to some extent the WPB affinity is shared by some of the present basalt of Iceland. Thus, whatever influenced the chemical composition of the basalt erupted at the time of the initial opening at the latitude of Iceland, also continues to influence it at present.

Richardson et al. (1984) also compared basalts from DSDP Site 112 and those from Rockall and found that they bore many similarities. On a discrimination diagram, basalt from Site 112 falls on the OFB side of the dividing line. Considering that the basalts from Rockall Plateau and those from Site 647 are depleted in incompatible trace elements and that they both fall within the OFB field (like the basalt from Site 112), one might conclude that they were generated from the same or similar magma sources. It is also possible that the same source is presently forming chemically similar basalts at the ridge crest at this latitude, if we follow the analogy that exists at the latitude of Iceland.

Strictly speaking, the basalt drilled on Rockall Bank should not be comparable in age to the basalt drilled at Site 647 , as they were formed at slightly different times, according to the plate-kinematic models for this region (Talwani and Eldholm, 1977; Kristoffersen and Talwani, 1977; Srivastava, 1978). Active seafloor spreading started between Greenland and Rockall Bank during Chron $\mathrm{C} 24$, although initial separation between the two may have started earlier. The basalts drilled on Rockall Bank show that these were formed during the reversed polarity between Chrons C24 and C25 (Roberts et al., 1984). The differ- 


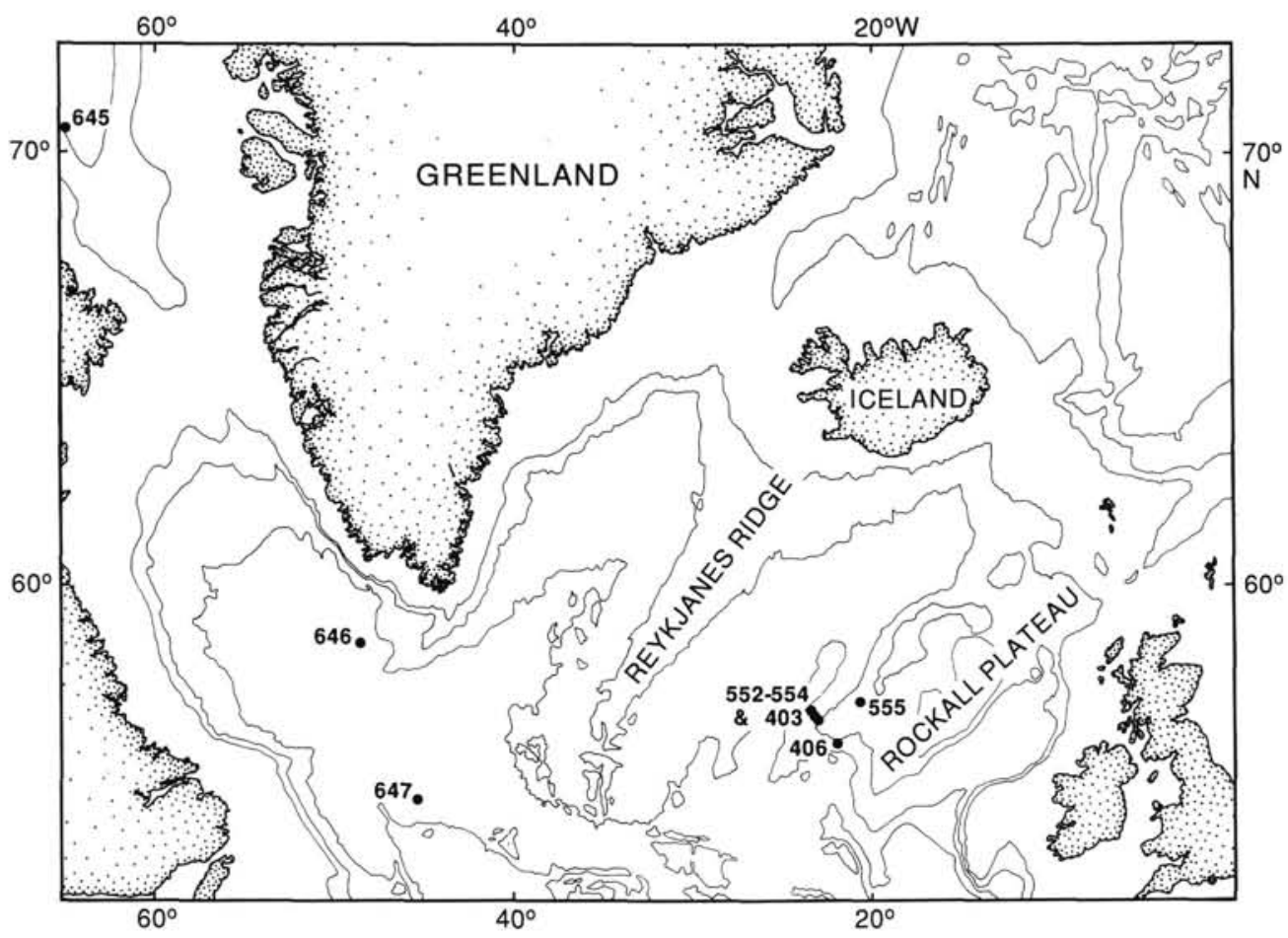

Figure 16. Map showing the locations of Sites 645, 646, and 647 in Baffin Bay and the Labrador Sea respectively. Also shown are DSDP Sites 552 to 555 and 403 and 406 on Rockall Plateau, where heat flows were measured.

ence in their ages is not significant (at the most, $2 \mathrm{Ma}$ ) and the above comparison to see if they both originated from similar sources should be valid. Figure 17 shows the positions of Sites $646,647,112$, and those on Rockall margin at the time of Chron $\mathrm{C24}$, as obtained using the plate kinematics of the North Atlantic given by Srivastava and Tapscott (1986). One can see from this figure that during Chron $\mathrm{C} 24$ all these sites were located fairly close to each other.

If the above differences between the basalts of Rockall margin and of the Greenland-Faeroe region are related to their distances from the hot spot now underlying Iceland, then by analogy the observed differences between Site 647 and Davis Strait basalts could also be related to the presence of a similar hot spot. Chronologically, the basalts of Baffin Island, West and East Greenland, and the Faeroes are of similar ages, but chemically enough differences exist between the two groups that Clarke (1977) proposed that they originated from very different sources. Even if the basalts of Davis Strait originated from a different magma source from that of the East Greenland basalts, the similarities in the differences between Davis Strait and Site 647 basalts and those between the Rockall Plateau and East Greenland basalts, suggest a similar mechanism for the two groups. Furthermore, the fact that the same magma source responsible for the formation of the crust at Site 647, at Site 112, and near Rockall Plateau may also be giving rise to similar crust under the ridge crest at this latitude implies that the Labrador Sea was also formed by seafloor spreading.

\section{Heat Flow and Ocean-Floor Subsidence}

Similarities in the differences of the Davis Strait and Site 647 basalts and between Iceland and Rockall Plateau basalts are not the only arguments that favor the presence of a hot spot under Davis Strait during Paleocene time; we find another similarity when we look at the shallowness of the basement rocks at these sites. We find that the basement depth at Site 647 is $800 \mathrm{~m}$ shallower than the world average for seafloor of that age $(56 \mathrm{Ma})$. In addition, the basement at Site 646 (based on the calculated value from seismic data) was found to be about $900 \mathrm{~m}$ too shallow for its age.

Similarly, the oceanic crust adjacent to the southwest margin of Rockall is $1700 \mathrm{~m}$ shallower than the average for that age. The question then arises is this the leftover effect from the hot spots located under Davis Strait and Iceland-Faeroe Ridge, respectively, when these regions were formed or something else? In the case of a hot spot, the excess elevation of the ocean crust is caused by intrusion of excessively light basaltic constituents. As a result of this, we now find that a large ocean-crust depth anomaly exists in the North Atlantic south of Iceland. We presume that this anomaly is associated with the hot spot now located under Iceland. For example, the Mid-Atlantic Ridge at the latitude of Site 647 is about $800 \mathrm{~m}$ shallower than the global average. This is about the same value as at Site 647 . The questions then arise-why is this so and what implication does it have for the Labrador Sea, where spreading ceased about Chron C13? Heat-flow measurements should be able to shed some light on this matter.

To examine this further, we calculated a subsidence curve for Site 647 following a procedure similar to that used at Site 645 and then looked at the heat-flow values measured at this and other sites of comparable ages in the North Atlantic. The resulting basement subsidence plotted vs. the square root of time is shown in Fig. 18. The error bars show the large uncertainty in the paleodepths at this site. Also shown is a calculated line for a thermally cooling oceanic crust of an age less than $60 \mathrm{Ma}$ (Parson and Sclater, 1977). Despite the inaccuracies inherent in calculations of this kind, Figure 18 shows that the crust at this site seems to have subsided in a fashion expected for normal oceanic crust, and the depth anomaly at this site does not arise due to 


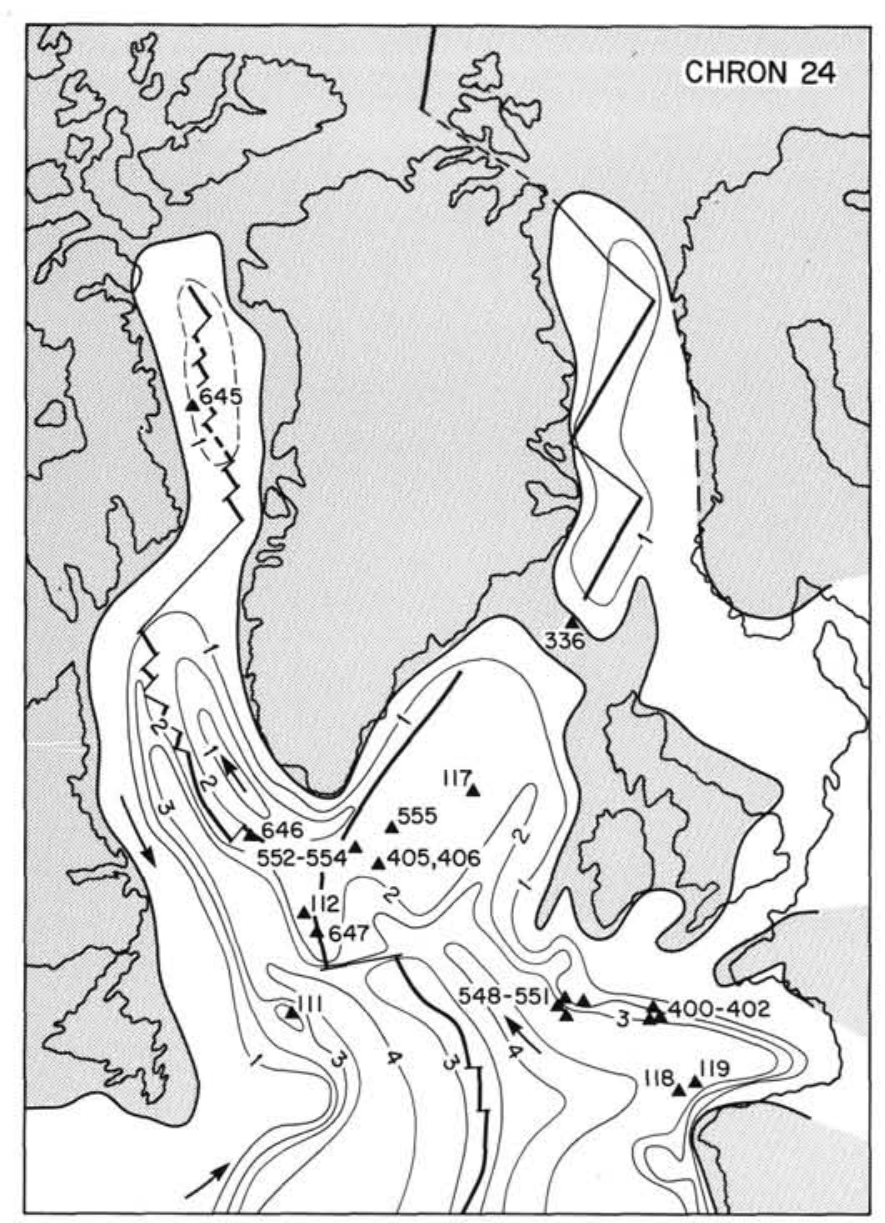

Figure 17. Paleogeographic positions of Greenland and Eurasia at anomaly 24 time ( $56 \mathrm{Ma}$ ). Also shown are the paleobathymetry (in kilometers) in the Labrador Sea, Norwegian-Greenland Sea, and the North Atlantic, together with expected paleocirculation. Reconstruction is based on the plate kinematics of the North Atlantic, as derived by Srivastava and Tapscott (1986). Paleobathymetry and other information based on Tucholke and McCoy (1986); compiled and modified in the Labrador Sea based on the drilling results. Triangles refer to ODP and DSDP sites.

the change in the rate of subsidence since the end of spreading (Chron C13) in the Labrador Sea. The calculations also show that a depth anomaly of $800 \mathrm{~m}$ existed at this site even at the beginning. This is based on the finding that on a global scale the normal oceanic crust is formed at water depths of $2500 \mathrm{~m}$. If the depth anomaly along the Reykjanes Ridge axis at the latitude of Site 647 is solely caused by the presence of a hot spot underneath Iceland, it then follows that the observed anomaly at Site 647 , which seems to have existed since the beginning, may have been caused by a hot spot.

Small thermal anomalies caused by geoid and topographical swells have been observed in regions subjected to hot-spot activity under old lithosphere (Detrick et al., 1988). To see if a similar situation existed for Site 647, we looked at the heat flows measured in the Labrador Sea. Pye and Hyndman (1972) had measured earlier heat flows in the Labrador Sea and Baffin Bay (Fig. 19). More recent measurements include those performed during the ODP site-survey cruise to the Labrador Sea (Srivastava et al., this volume) and the downhole measurements at Site 646 conducted during Leg 105 (Louden et al., this volume). The earlier measurements show consistently lower heat-flow values, compared with those obtained from the surface and downhole

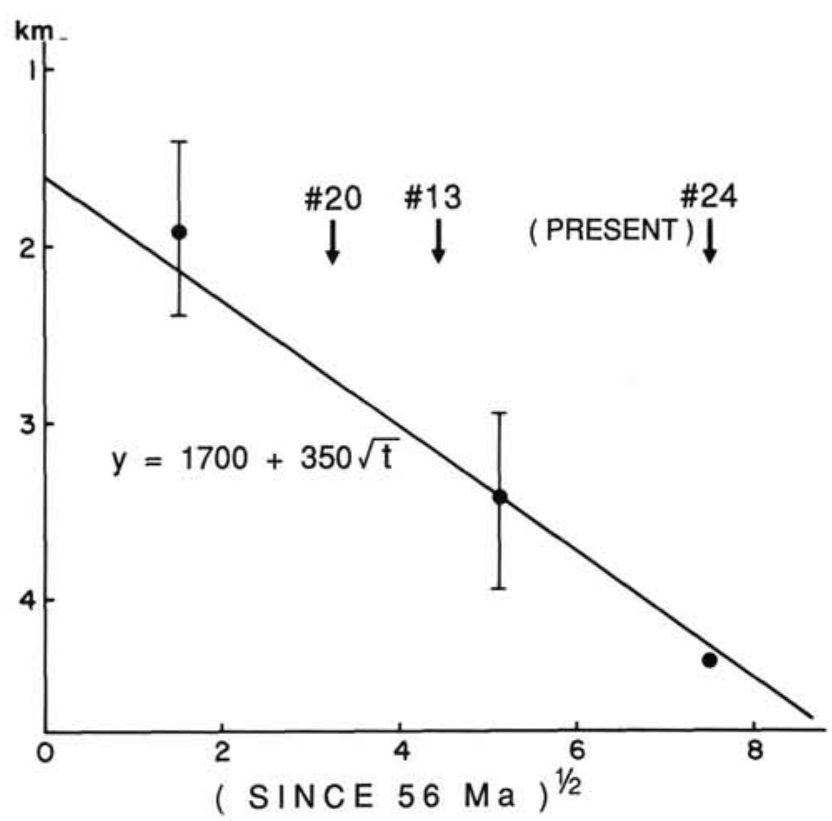

Figure 18. Plot of rate of subsidence vs. square root of age since $56 \mathrm{Ma}$ for Site 647 .

measurements (Fig. 19). Although we believe that these recent values are more representative of the heat-flow values at these two sites, mainly because of the close agreement between the surface and downhole values at Site 646, we do not understand why the earlier measurements gave consistently lower values. A higher heat-flow value was observed at Site 646 (average of 79 $\left.\pm 4 \mathrm{~mW} / \mathrm{m}^{2}\right)$, compared with that at Site $647\left(74 \pm 3 \mathrm{~mW} / \mathrm{m}^{2}\right)$, even though both sites are located on crust of equal age (Chron $\mathrm{C} 24,56 \mathrm{Ma})$. For normal oceanic crust of this age the coolingplate model of Parson and Sclater (1977) predicts a heat-flow value of about $63 \mathrm{~mW} / \mathrm{m}^{2}$. This agrees with the values obtained by Pye and Hyndman (1972), but is lower than previous values and those obtained at Sites 647 and 646. If these values are considered representative of the heat-flow values in the Labrador Sea, then the most obvious explanation for the higher-than-normal heat-flow values is a residual thermal anomaly, which may be related to the hot-spot activity under the Davis Strait region.

The heat-flow values for Sites 647 and 646, when compared with standard oceanic lithosphere cooling models as shown in Fig. 20, suggest that they correspond to a 35-Ma crust formed at an initial depth of $2000 \mathrm{~m}$. This age corresponds to about the time of cessation of spreading in the Labrador Sea. This thermal age thus suggests that the lithosphere here might have been kept from cooling by a wide zone of hot-spot-related upwelling, until spreading stopped before Chron $\mathrm{C} 13$ (Louden et al., this volume). The cooling became normal once the hot-spot activity shifted from the Labrador Sea to that under Iceland.

On the other hand, the rate of subsidence at Site 647 (Fig. 18 ), although not definitive, suggests a normal behavior since the beginning. If real, the thermal anomaly would account for some of the depth anomaly $(500 \mathrm{~m})$ observed at the site. However, if we assume that the zero-age depth of the crust at this site was $2.0 \mathrm{~km}$, as the heat-flow values suggest (Fig. 20), then most of the depth anomaly can be accounted for. As Louden et al., (this volume) point out, this excess elevation can be caused by higher temperatures within the asthenosphere or a thicker crust having a mean density of $6 \%$ less than normal. The former is unlikely as it would create an additional $10 \%$ heat-flow anomaly, which was not observed. On the other hand, Louden et al. 


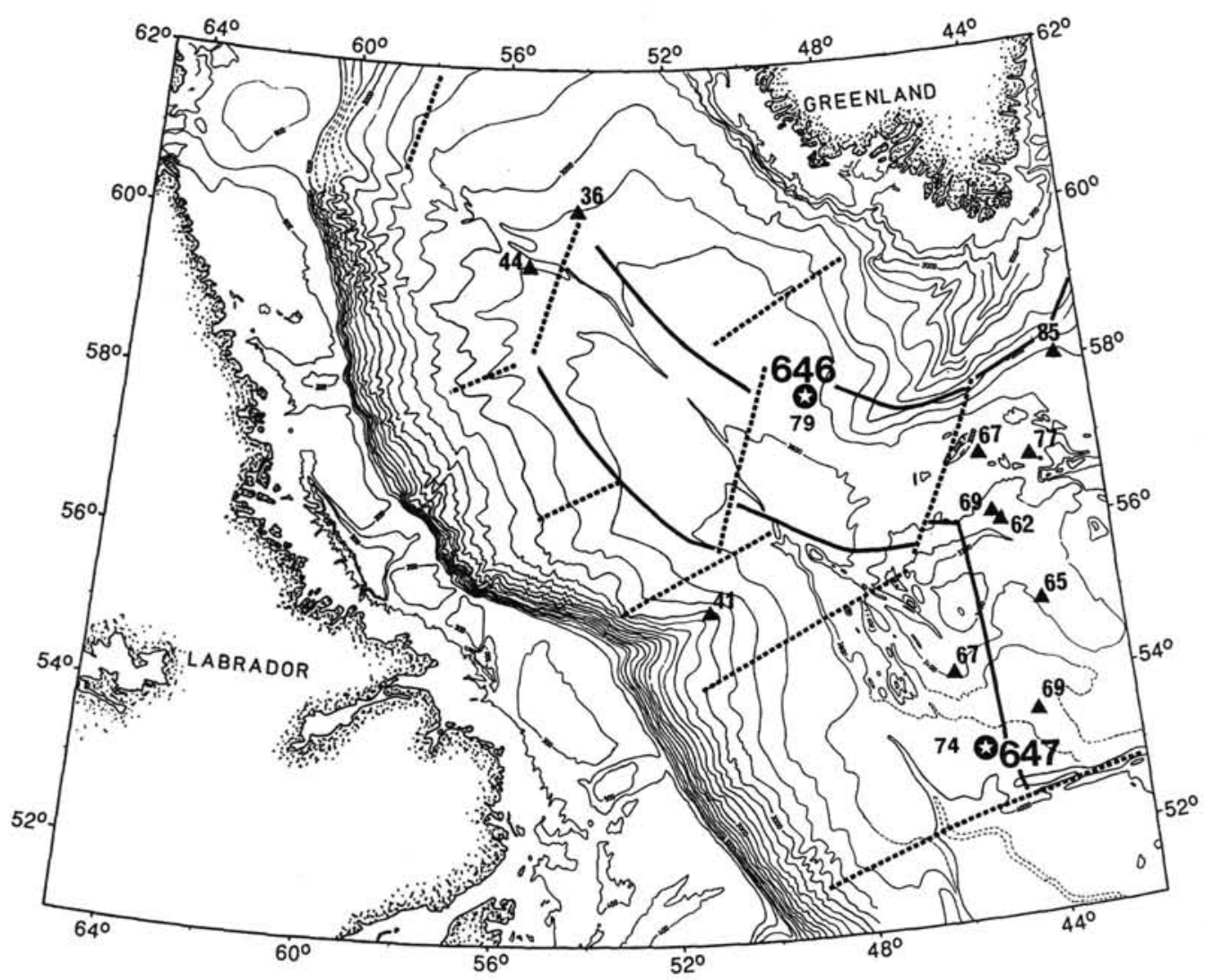

Figure 19. Compilation of heat-flow measurements in the Labrador Sea. Values are in units of $\mathrm{mW} / \mathrm{m}^{2}$ (after Louden et al., this volume).

(this volume) have shown that the heat-flow values at Site 646 could be raised by $10 \%$ to $15 \%$ if we take into account the thermal blanketing effect resulting from high sedimentation rate $(90$ $\mathrm{m} / \mathrm{m}$.y.) at this site. However, this is contrary to the fact that Site 647 , which overlies crust of comparable age as Site 646, does not show high heat-flow values even though the rate of sedimentation at this site never exceeded $46 \mathrm{~m} / \mathrm{m}$.y. However, some possibilty exists that the crust at this site may be unusual in the sense that a high-velocity layer $3(7.5 \mathrm{~km} / \mathrm{s})$ was observed here (Srivastava et al., this volume). Such high velocities, although they preclude the possibility of lower crustal densities, have been observed in regions of thickened crust near continental margins that are thought to be affected by hot-spot activity (White et al., 1988). Detailed refraction data will be needed to substantiate such a relationship at this site.

Heat flows were also measured on Rockall Plateau (Hyndman and Roberts, 1987). These measurements show that most of the values lie between 62 and $68 \mathrm{~mW} / \mathrm{m}^{2}$, with a single value of $71 \mathrm{~mW} / \mathrm{m}^{2}$ for this region (Fig. 21). These are not drastically different from a value of $63 \mathrm{~mW} / \mathrm{m}^{2}$, expected for a $58-\mathrm{Ma}$ crust from a cooling-plate model for this region (between Chrons C24 and C25). This is contrary to what has been observed for the Labrador Sea, where recent measurements show consistently higher-than-normal values. If real, and if these higher values in the Labrador Sea are indicative of a residual effect from a Davis Strait hot spot, then one would expect the effect to be the same on Rockall Plateau as from the Iceland hot spot. This becomes specially important because a comparison of the basalts between the two regions shows that they were probably derived from a similar or an identical magma source. Thus, the difference in the heat-flow values between the two regions is most surprising. Possibly, the values observed on Rockall margin are dif- ferent in a sense, as they also are influenced by stretching of the crust under this region. These values may be higher than normal for the stretched continental crust that apparently underlies part of this region. Hyndman and Roberts (1987), however, do not think so.

\section{Davis Strait}

Drilling results and other geophysical measurements in the Labrador Sea, as summarized above, favor the possibility of the presence of a hot spot under Davis Strait during the Paleocene. The implications of such an interpretation are significant for deciphering this region's subsidence history for paleocirculation through the region. To relate the findings from Baffin Bay to those of the Labrador Sea, we found it essential to estimate what kind of bathymetric conditions existed through the Davis Strait region in the past for any exchange of water between between the two. For this, we used the age-depth relationship given by Parson and Sclater (1977).

Parsons and Sclater (1977) showed that depth, $d$, in meters of normal oceanic floor, can be related to its spreading age, $t$, in $\mathrm{Ma}$, by the empirical relationship:

$$
d(t)=2500+350 \sqrt{t} \text { for } t<50 \mathrm{Ma}
$$

and

$$
d(t)=6400-3200 \exp (-t / 62.8) \text { for } t>30 \mathrm{Ma} .
$$

If the crust is formed above sea level, so that a load of increasing water depth is not present to assist the subsidence until the surface is carried below sea level, the initial subaerial stage of subsidence is slower by a factor of $\left(1-\rho_{w} / \rho_{a}\right)$, where $\rho_{w}$ is 


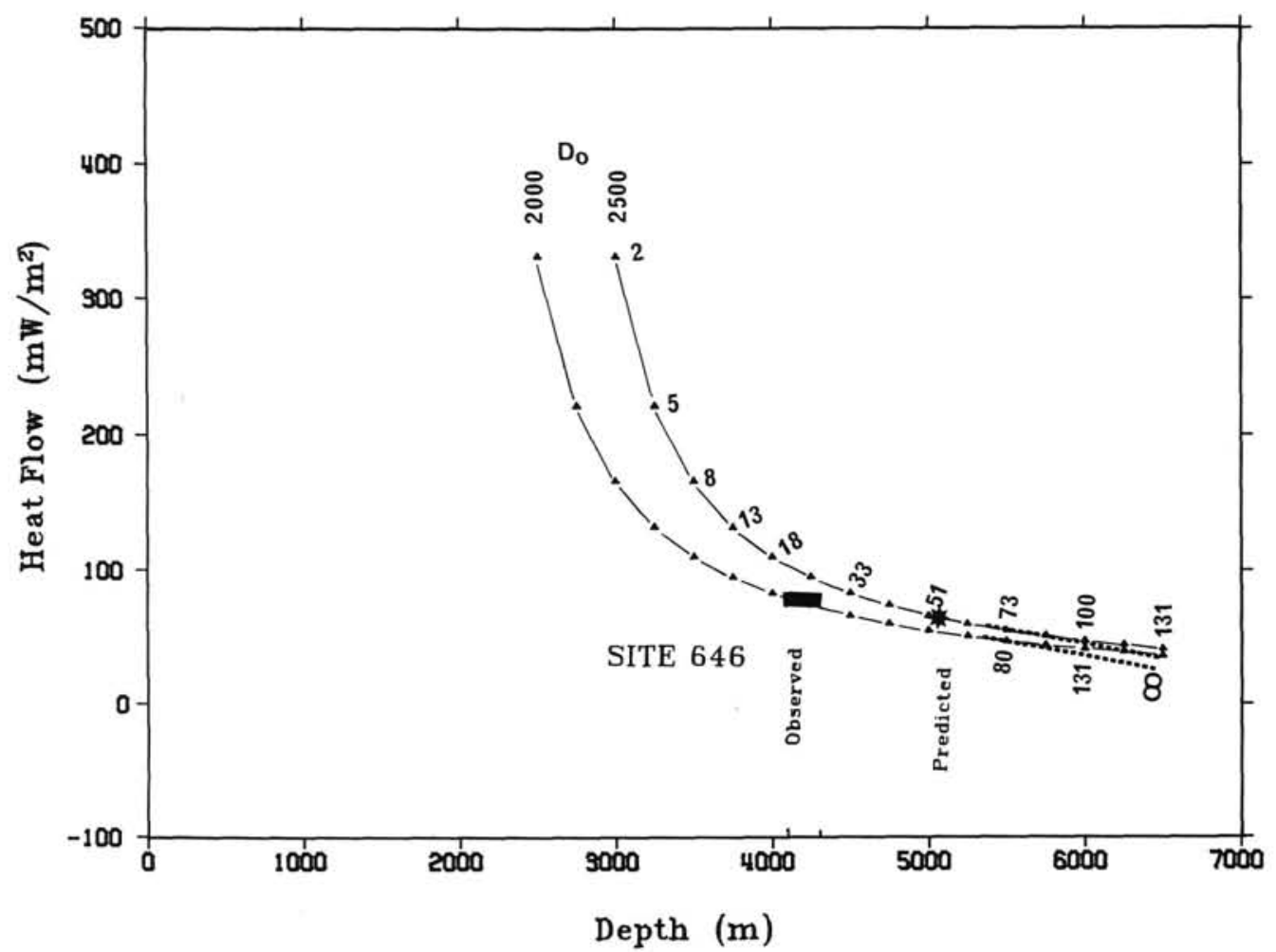

Figure 20. Plot of heat flow vs. basement depth observed in the Labrador sea (solid bar) compared to predictions (star) from theoretical half-space (solid lines) and plate models (broken lines) for differing values of zeroage depth $(D o)$ or background heat flow, as given by Louden and Wright (in press). Numbers along curves indicate age predictions for each model (after Louden et al., this volume).

the density of sea water and $\rho_{a}$ is the density of the underlying asthenosphere. The subaerial subsidence at time $t$ after formation is approximately given by $240 t^{1 / 2}$. If the age of formation and depth are known, it is possible to use the above formulas to infer the history of elevation since formation, even when the surface was initially above sea level. However, these simple formulas may not accurately depict the actual subsidence in cases where the formation is abnormal, as under Iceland, or in hotspot regions, where processes such as erosion, sedimentation, mantle convection, and underplating may modify the subsidence (Bott, 1983).

For the Davis Strait region, it is difficult to estimate the age of the underlying crust. The plate-kinematic solution for the Labrador Sea (Srivastava and Tapscott, 1986) suggests that motion is largely strike slip through this region, with a small amount of extension starting in Late Cretaceous and continuing until early Oligocene. However, considering that major volcanism took place in this region in late Paleocene (Clarke, 1977), when large quantities of basalt were erupted on Baffin Island and West Greenland, the whole subsidence was disrupted at this time. The region has not been affected by any other tectonic episodes since then. Thus, in our calculations, we consider late $\mathrm{Pa}$ leocene $(60 \mathrm{Ma})$ as the age for the crust under this region. If we use 500 to $750 \mathrm{~m}$ as the mean present depth in Davis Strait region, and work backward, the above expressions tell us that the Davis Strait sill could not have subsided below sea level before $30 \mathrm{Ma}$ ago, at about mid-Oligocene time. Further, the strait may have stood about 1 to $1.3 \mathrm{~km}$ above sea level in late Paleocene time, creating a land bridge between Baffin Island and Greenland.

The above calculations can only be considered as a guide because of the complexity in the nature of the crust underlying this region. The rate of subsidence would be much slower for this region if it contained fragments of continental material. In that case, it would be likely that the region may have subsided below sea level as late as mid to late Miocene time, allowing the northern waters from Baffin Bay to flow south into the Labrador Sea, as is implied by the findings from Baffin Bay drilling.

As in Davis Strait, a sill also exists in the northeast Atlantic between Greenland and Europe known as the Greenland-Iceland-Faeroe Ridge. This ridge is anomalously shallow for its age (like the Davis Strait sill) and forms a barrier for the exchange of deep water between the Atlantic and the Arctic oceans. Geophysical features have been measured extensively across it, and some DSDP holes have been drilled (Talwani et al., 1976). The ridge is now generally regarded to have started to form when Greenland separated from Europe in late Paleocene and to have continued to form since then. Iceland now forms part of this ridge. Scientists have found it difficult to get its history of subsidence because of a lack of sediment cover and reliable crustal ages. The ridge is estimated to have subsided below sea level by early Miocene (Vogt, 1972) to late Oligocene (Talwani et al., 1976) time. Thus, large barriers may have existed on both sides of Greenland as late as Oligocene time, which argues against any exchange of water between the Arctic and Atlantic oceans. The implications of this on the findings from the Labrador and Norwegian-Greenland seas are discussed by Arthur et al. (this volume).

\section{CONCLUSIONS}

Drilling at two sites in the Labrador Sea and at one site in Baffin Bay show that:

1. The crust underlying the two Labrador Sea sites is oceanic in nature. This comes largely from the detailed petrological and chemical analyses performed on the basalts obtained from 


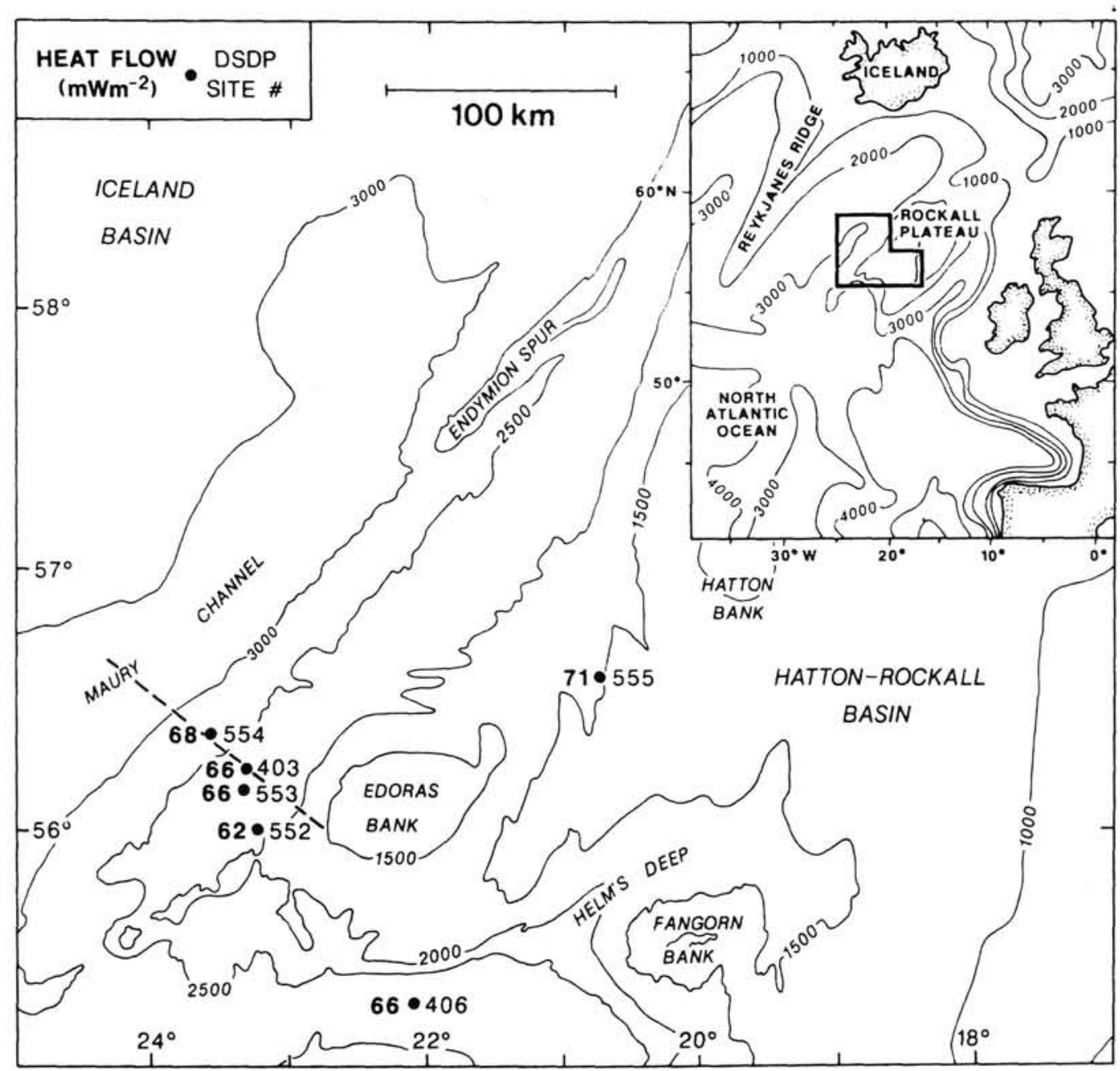

Figure 21. Heat-flow values (in $\mathrm{mW} / \mathrm{m}^{2}$ ) measured at DSDP Sites 552 to 555 and 403 and 406 on the Rockall Plateau (after Hyndman and Roberts, 1987).

one of the sites. These analyses show that the basalt recovered here is similar to the early Baffin Island basalt, but differs from later Baffin Island and West Greenland basalts. The basalts from Site 647 show typical OFB affinities, while the later Baffin Island and West Greenland basalts show WPB affinities. Similar affinities were found among the basalts from East Greenland, the Faeroe Islands, and the western margin of Rockall Plateau. Because of the proximity of these basalts to Iceland, we interpreted that these variations in their affinities may arise from the presence of a hot spot presently lying under Iceland. Furthermore, the basalts from Site 647 and those from the western margin of Rockall Plateau show similarities in their chemical compositions, suggesting that they may have erupted from the same magma source. The differences and similarities between Davis Strait region and Site 647 basalts thus could be attributed to the presence of a hot spot under Davis Strait during the Paleocene.

2. The oceanic crust at Sites 647 and 646 is anomalously shallow (about $800 \mathrm{~m}$ ), compared with the world average depth for crust of that age. A similar anomalous situation is found on the Reykjanes Ridge axis at the latitude of Site 647. If this depth anomaly diagnoses the presence of a hot spot now located under Iceland, it follows that the observed anomalies at Sites 646 and 647 could be associated with the presence of a hot spot under Davis Strait during the Paleocene.
3. Heat flows measured at Sites 646 and 647 show values of 79 and $74 \mathrm{~mW} / \mathrm{m}^{2}$, respectively. These values, if correct, are $20 \%$ to $25 \%$ higher than expected for their age from standard lithospheric models. Furthermore, when the measured values are plotted on the depth vs. heat-flow curves, for standard oceanic lithospheric cooling models, they show the age for the crust as $35 \mathrm{Ma}$ and the zero-age depth as $2000 \mathrm{~m}$. This implies that the lithosphere may been kept from cooling by some widespread hot-spot activity, until at least spreading stopped in the Labrador Sea about $35 \mathrm{Ma}$ ago. But on the contrary, the observed basement subsidence curve at Site 647 does not show any change in the rate of subsidence at $35 \mathrm{Ma}$. The zero-age depth of $2000 \mathrm{~m}$ would account for at least half of the depth anomaly $(500 \mathrm{~m})$ that is found in most of the Labrador Sea. The other half would then require either thicker crust or hotter asthenosphere associated with the hot spot.

4. The age of the basalt drilled at Site 647 was found to be $56 \mathrm{Ma}$, based on the age of the sediments immediately overlying it. This age closely agrees with the basement age that was initially assigned according to the identification of magnetic Chron $\mathrm{C} 24$, which overlies this site. Such a correlation supports the identification of the magnetic anomalies in the Labrador Sea and validates the seafloor-spreading model for this region.

5. The subsidence of the basement observed at the Baffin Bay site, at least since Oligocene, follows the trend expected 
from a thermally cooling lithosphere. It is not clear if a similar trend existed earlier, but extrapolation of the observed trend shows that it could have remained the same since $63 \mathrm{Ma}$. This value agrees with the plate-tectonic model suggested for this region.

\section{ACKNOWLEDGMENTS}

We thank the captain and crew of the JOIDES Resolution, the Sedco drilling crew, and the ODP technicians for their help during Leg 105. We are particularly grateful to Lamar Hayes, ODP Operations Superintendent, who played a key role in collecting core samples. We acknowledge the efforts of the shipboard party (particularly, Brad Clement), who helped through numerous discussions and by furnishing data. We thank Charlotte Keen, Hugh Miller, Ron Macnab, and Barry Clarke for their comments and observations on the manuscript. We are grateful to Dale Issler for his help with calculating basement subsidences at different sites. Illustrations were prepared by the drafting and illustration section of the Bedford Institute of Oceanography. This is Geological Survey of Canada Contribution No. 43588.

\section{REFERENCES}

Berggren, W. A., Kent, D. V., and Van Couvering, J. A., 1986a. Neogene geochronology and chronostratigraphy. In Snelling, N. J. (Ed.), Geochronology and the Geological Time Scale. Geol. Soc. (London) Mem., 10:211-250.

Berggren, W. A., Kent, D. V., and Flynn, J. J., 1986b. Paleogene geochronology and chronostratigraphy. In Snelling, N. J. (Ed.), Geochronology and the Geologic Time Scale. Geol. Soc. (London) Mem., 10:141-195.

Bott, M.H.P., 1983. Deep Structure and geodynamics of the GreenlandScotland Ridge: an introductory review. In Bott, M.H.P., Saxov, S., Talwani, M., and Thiede, J. (Eds.), Structure and Development of the Greenland Scotland Ridge, New Methods and Concepts: New York (Plenum Press), 3-10.

Clarke, D. B., 1977. The Tertiary volcanic province of Baffin Bay. In Baragar, W.R.A., Coleman, L. C., Hall, J. M. (Eds.), Volcanic Regimes. Geol. Assoc. Can. Spec. Pap., 16:445-460.

Detrick, R. S., White, R. S., Courtney, R. C., and Von Herzen, R. P., 1988. Heat flow on mid-plate swells. In Wright, J. A., and Louden, K. E. (Eds.), Handbook of Marine Heat Flow: Boca Raton (CRC Press).

Gradstein, F. M., and Srivastava, S. P., 1982. Aspects of Cenozoic stratigraphy and paleoceanography of the Labrador Sea and Baffin Bay. Palaeoclimatol., Palaeogeogr., Palaeoecol., 30:261-295.

Grant, A. C., 1988. Depth to basement of the continental margin of eastern Canada. Geol. Surv. Can. Map, 1707A (scale 1:5,000,000),

Henderson, G., Schiener, E. J., Risum, J. B., Croxton, C. A., and Anderson, B. B., 1981. The west Greenland basin. In Ken, J. W., and Fergusson, A. J. (Eds.), Geology of the North Atlantic Borderlands. Can. Soc. Pet. Geol. Mem., 7:399-428.

Hyndman, R. D., 1973. Evolution of the Labrador Sea. Can. J. Earth Sci., 10:637-644.

1975. Marginal basins of the Labrador Sea and the Davis Strait hot spot. Can. J. Earth Sci., 12:1041-1045.

Hyndman, R. D., and Roberts, D. G., 1987. Deep Sea Drilling Project heat flow and models of the rifted west Rockall margin. J. Geophys. Res., 92:9376-9384.

Issler, D. R., and Beaumont, C., 1988. Thermal and subsidence history of the Labrador and West Greenland continental margins. In Beaumont, C., and Tankard, A. J. (Eds.), Sedimentary Basins and BasinForming Mechanism. Can. Soc. Pet. Geol. Mem., 12:45-70.

Jackson, H. R., Keen, C. E., Falconer, R.K.H., and Appleton, K. P., 1979. New geophysical evidence for seafloor spreading in central Baffin Bay. Can. J. Earth Sci., 16:2122-2135.

Joron, J. L., Bougolt, H., Maury, R. C., Bohn, M., and Despraries, A., 1984. Strongly depleted tholeiites from the Rockall Plateau margin, North Atlantic: Geochemistry and mineralogy. In Roberts, D. G., and Schnitker, D., et al., Init. Repts. DSDP, 81: Washington, D.C. (U.S. Govt. Printing Office), 783-795.

Keen, C. E., 1979. Thermal history and subsidence of rifted continental margins-evidence from wells on the Nova Scotian and Labrador shelves. Can. J. Earth Sci., 16:505-522.
Keen, C. E., and Barrett, D. L., 1972. Seismic refraction studies in Baffin Bay: an example of a developing ocean basin. Geophys. J. Roy. Astron. Soc., 30:253-271.

Keen, M. J., and Clarke, D. B., 1974. Tertiary basalts of Baffin Bay: Geochemical evidence for a fossil hot spot. In Kristiansson, L. (Ed.), Proc. NATO Conference on Geodynamics of Iceland and the North Atlantic Area: Dordrecht-Holland (D. Reidal), 127-137.

Kerr, J. W., 1967. A submerged continental remnant beneath the Labrador Sea. Earth Planet. Sci. Lett., 2:283-289.

Klose, G. W., Malterre, E., McMillan, N. J., and Zinkan, C. G., 1982. Petroleum exploration offshore southern Baffin Island, Northern Labrador Sea, Canada. In Embry, A. F., and Balkwill, H. R. (Eds.), Arctic Geology and Geophysics: Calgary (Can. Soc. Pet. Geol.), Mem. 8:245-265.

Kristoffersen, Y., and Talwani, M., 1977. Extinct triple junction south of Greenland and the Tertiary motion of Greenland relative to North America. Geol. Soc. Am. Bull., 88:1037-1049.

Laughton, A. S., Berggren, W. A., et al., 1972. Init. Repts. DSDP, 12: Washington (U.S. Govt. Printing Office).

McWhae, J.R.H., 1981. Structure and spreading history of the northwestern Atlantic region from the Scotian shelf to Baffin Bay. In Kerr, J. W., Fergusson, A. J., and Machan, L. C. (Eds.), Geology of North Atlantic Borderlands: Calgary (Can.Soc. Pet. Geol.), Mem. 7:299-332.

Miller, K. G., and Tucholke, B. E., 1983. Development of Cenozoic abyssal circulation south of the Greenland-Scotland Ridge. In Bott, M.H.P., Saxov, S., Talwani, M., and Thiede, J. (Eds.), Structure and Development of the Greenland-Scotland Ridge: New York (Plenum), 549-589.

Morton, A. C., and Taylor, P. N., 1987. Lead isotope evidence for the structure of the Rockall dipping-reflector passive margin. Nature, 326:381-383.

Oakey, G. N., Currie, C., and Durling, P., 1988. A digital compilation of depth to basement of the east coast of Canada and adjacent areas. Geol. Surv. Can. Open File \#1964.

Parsons, B., and Sclater, J. G., 1977. An analysis of the variation of ocean floor bathymetry and heat flow with age. J. Geophys. Res., $82: 803$.

Pye, G. D., and Hyndman, R. D., 1972. Heat flow measurements in Baffin Bay and the Labrador Sea. J. Geophys. Res., 77:938.

Rice, P. D., and Shade, B. D., 1982. Reflection seismic interpretation and seafloor spreading history of Baffin Bay. In Embry, A. F., and Balkwill, H. R. (Eds.), Arctic Geology and Geophysics: Calgary (Can. Soc. Pet. Geol.), Mem. 8:245-265.

Richardson, C., Oakley, P. J., and Cann, J. R., 1984. Trace and major element geochemistry of basalts from Leg 81. In Roberts, D. G., Schnitker, D., et al., Init. Repts. DSDP, 81: Washington (U.S. Printing Office), 795-807.

Roberts, D. G., Schnitker, D., et al., 1984. Init. Repts. DSDP, 81: Washington (U.S. Govt. Printing Office).

Roest, W. R., and Srivastava, S. P., 1989. Seafloor spreading history, I: magnetic anomalies along track. In Bell, J. S. (Coordinator), East Coast Basin Atlas Series: Labrador Sea, Atlantic Geoscience Centre. Geol. Surv. Can. Publ., 98-99.

Rolle, F., 1985. Late Cretaceous-Tertiary sediments offshore central West Greenland: lithostratigraphy, sedimentary evolution, and petroleum potential. Can. J. Earth Sci., 22:1001-1019.

Roots, W. D., and Srivastava, S. P., 1984. Origin of the marine magnetic quiet zones in the Labrador and Greenland Seas. Mar. Geophys. Res., 6:395-408.

Srivastava, S. P., 1983. Davis Strait: structures, origin, and evolution. In Bott, M.H.P., Saxov, S., Talwani, M., and Thiede, J., (Eds.), Structure and Development of the Greenland-Scotland Ridge; New Methods and Concepts: NATO Conf. Ser., IV(8):159-189.

1988. Geophysical maps and geological sections of the Labrador Sea. Geol. Surv. Can. Pap., 85-16.

1978. Evolution of the Labrador Sea and its bearing on the early revolution of the North Atlantic. Geophys. J. Roy. Astron. Soc., 52:313-357.

Srivastava, S. P., Arthur, M. A., et al., 1987. Proc. ODP, Init. Repts., 105: College Station, TX (Ocean Drilling Program).

Srivastava, S. P., Falconer, R.K.H., and MacLean, B., 1981. Labrador Sea, Davis Strait, Baffin Bay: geology and geophysics-a review. In 
Kerr, J. W., Fergusson, A. J., and Machan, L. D. (Eds.), Geology of the North Atlantic Borderlands: Calgary (Can. Soc. Pet. Geol.), Mem. 7:333-398.

Srivastava, S. P., MacLean, B., Macnab, R. F., and Jackson, H. R., 1982. Davis Strait: structure and evolution as obtained from a systematic geophysical survey. In Embry, A. F., and Balkwill, H. R. (Eds.), Arctic Geology and Geophysics: Calgary (Can. Soc. Pet. Geol.), Mem. 8:267-278.

Srivastava S. P., and Roest, W., 1989. Seafloor spreading history, II to IV: plate reconstructions. In Bell, J. S. (Coordinator), East Coast Basin Atlas Series: Labrador Sea, Atlantic Geoscience Centre. Geol. Surv. Can., 100-109.

Srivastava, S. P., and Tapscott, C. R., 1986. Plate kinematics of the North Atlantic. In Vogt, P. R., and Tucholke, B. E. (Eds.), The Geology of North America: The Western Atlantic Region: Boulder (Geol. Soc. Am.), DNAG Ser., Vol. M., Spec. Publ., 589-404.

Talwani, M., and Eldholm, O., 1977. Evolution of the NorwegianGreenland Sea. Geol. Soc. Am. Bull., 88:969-999.

Talwani, M., Udintsev, G., and Shirshov, P. P., 1976. Tectonic Synthesis. In Talwani, M., Udintsev, G., et ai., Init. Repts. DSDP, 81: Washington (U.S. Govt. Printing Office), 1213-1242.
Tucholke, B. E., and Fry, V. A., 1986. Maps of Sediment Thickness and Depth to Basement in the northwest Atlantic Ocean Basin Tulsa, OK (AAPG).

Tucholke, B. E., and McCoy, F. W., 1986. Paleographic and paleobathymetric evolution of the North Atlantic Ocean. In Vogt, P. R., and Tucholke, B. E. (Eds.), The Geology of North America: The Western North Atlantic Region: DNAG Ser., Vol. M, Spec. Publ., 589602.

Vogt, P. R., 1972. The Faeroe-Iceland-Greenland, a seismic ridge and the western boundary under current. Nature, 239:79-86.

Watts, A. B., and Stickler, M. S., 1979. Subsidence and eustasy at the continental margin of eastern North America. In Talwani, M., Hay, W. W., and Ryan, W.B.F. (Eds.), Deep Drilling Results in the Atlantic Ocean. Continental Margins and Paleoenvironment. Am. Geophys. Un. Maurice Ewing Ser., 3:218-234.

White, R. S., Spence, G. D., Fowler, S. R., McKenzie, D. P., Westbrook, G. K., and Bowen, A. N., 1987. Magmatism at rifted continental margins. Nature, 330:439-444.

Date of initial receipt: 31 March 1988

Date of acceptance: 3 January 1989

Ms 105B-163 